\title{
PUBLIC FINANCIAL MANAGEMENT REFORM IN SOUTH AFRICAN PROVINCIAL BASIC EDUCATION DEPARTMENTS
}

\author{
TANIA AJAM* AND DAVID J. FOURIE \\ University of Pretoria, South Africa \\ * Correspondence to: T. Ajam, School of Public Management and Administration, University of Pretoria, \\ Private Bag X20, Hatfield, Pretoria, Gauteng, 0028, South Africa. E-mail: tania.ajam@gmail.com
}

\section{SUMMARY}

Since the transition to democracy in 1994, the South African government has engaged in a sustained programme of public financial management (PFM) reform across the national, provincial and local spheres of government. This study evaluates the progress of the nine provincial education departments (PEDs) in implementing the Public Finance Management Act of 1999, and explores the factors which facilitated or impeded reform. A public financial management progress (PFMP) index is constructed to track each PED's performance from 1997/98 to 2013/14 and then used to benchmark its progress over time and relative to the education sector as a whole. The indicators comprising the PFMP index assess key PFM functions (budgeting, accounting, financial auditing and audits of performance information), financial leadership and the effectiveness of governance institutions such as audit committees. While there has been considerable progress in PFM, distinct differences in the quality and effectiveness of PFM practices across the nine PEDs remain. Stable top administrative leadership, availability of PFM skills, varying degrees of accountability and departmental capacity 
to establish PFM systems that conform to new accounting standards drive variances in reform outcomes.

KEYWORDS: Public financial management reform, New Public Management, performance information, leadership, fiscal governance, fiscal institutions.

\section{INTRODUCTION}

Despite the thrust towards evidence-based policy-making and results-based reform, there has been comparatively limited systematic analysis of the results or outcomes of public financial management (PFM) reforms. This is true even of countries such as New Zealand and Australia on which many PFM reforms, both in advanced and developing countries, were modelled (Jones and Kettl, 2003; Guthrie et al., 2005).

This has led to public management reforms being disparaged as "faith-based" rather than evidence-based (Pollitt, 1995). Paradoxically, while recent public management reforms have required public sector organizations to focus on results and assess outcomes while minimising costs, this rigour has not been applied to public management reforms, supporting the claim that "the international management reform movement has not needed results to fuel its onward march" (Pollit and Boukaert, 2011: 159).

This lacuna is even more pronounced in developing country reform initiatives. Their PFM systems operate in political, legal, institutional, historical, cultural and socioeconomic contexts which are vastly different from their developed country counterparts (Caiden and Wildavsky, 1970; Schick, 1998; Hepworth, 2015). In particular, there may be distinct divergences between their formal and informal institutions, with the latter 
strongly influencing the actual administrative decisions, incentives and behaviours which condition reform outcomes. For instance, Turner (2015) identified a range of factors which inhibited public administrative reform in Cambodia, ranging from political patronage, weak accountability systems and bureaucratic dysfunction. The absence of these factors conversely increases the probability of reform success. Theoretical approaches to PFM reform that seek to articulate a "theory of change" behind PFM reform design and implementation, especially in developing countries, remain under-developed (Cummings, 2015).

The objective of this study is to assess the progress of the nine provincial departments of education (PEDs) in South Africa in implementing the Public Finance Management Act of 1999 (PFMA), a key pillar of the Government's PFM reform programme. It also explores the factors which have facilitated or impeded reform. Through the construction an index tracking PFM implementation progress, this article offers a quantitative perspective on PFM reform implementation in South Africa, a middle income country with pervasive poverty, inequality and unemployment. This approach would also be highly applicable to other developing countries which implementing PFM reform in a decentralized environment with multi-level government.

\section{PFM REFORM IMPLEMENTATION, ISOMOPHISM AND ITERATIVE ADAPTIVE IMPLEMENTATION PROCESSES}

The ongoing quest for alternative governance models and public administration models to foster development effectively is likely to continue as developed countries grapple with the formidable challenges of combatting poverty, extreme inequality, climate change and corruption while improving the accessibility and quality public services and 
citizens' perceptions of the legitimacy, accountability and responsiveness of government. The extent to which such models and knowledge can be transferred and adapted to other contexts is likely to continue to feature prominently public administration discourse (Puppim de Oliviera, Jing and Collins, 2015). Despite low success rates (World Bank, 2008; Andrews, 2013; Gao, 2015, Rinnert, 2015), developing countries are likely persist in pursuing reforms such as decentralization, PFM and other forms of civil service and administrative reform.

Failure of reforms in developing countries have been attributed to inappropriate reform design, based on the ill-conceived replication of sophisticated administrative and conceptual models (such as the New Public Management) formulated in advanced countries. These transplanted models tended to be incongruent with, and dysfunctional within, developing country contexts with weak institutional, government and market structures and an underdeveloped civil society (Bunse and Fritz, 2012; Andrews, 2013; Shamsul Haque, 2013; Repucci, 2014). Even within the same country, implementation outcomes can vary markedly across public sector entities pursuing the same reform objectives, depending on highly context specific features. These include, inter alia, fluctuating political commitment to reform, capacity and resource constraints, external shocks, the interaction between political and bureaucratic elites and historical administrative development trajectories (Guthrie, Humphrey, Jones and Olson, 2005; Pollit \& Bouckaert, 2011; Rinnert 2015). How reforms are implemented crucially affects their ultimate impact (or lack thereof).

PFM reform implementation, as opposed to reform design, has however attracted far less attention in the literature (Diamond, 2003; Allen, 2009). While politicians and civil servants at national level typically define reform objectives, their counterparts at 
subnational level may face different incentives to advance or hinder reform implementation (Smoke, 2015). Implementation processes have to strike a delicate balance between adapting to the specific context in which they are implemented, on the one hand, and being so diluted, captured and distorted by various interest groups during implementation, that their objectives are subverted (Andrews 2013, Smoke 2015).

Newer, more pragmatic post-NPM reform approaches caution against implementing over-ambitious "one size fits all" reform templates based on international best practice in unstable political and administrative environments which lack the capacity and resources to internalize and sustain these changes fully, the institutions to shape the incentives of stakeholders appropriately in support of meaningful reform and under the lying social norms and administrative values conducive to lasting change. A synopsis of the recent literature by Brinkerhof and Brinkerhoff (2015) highlighted four key themes in crafting viable and effective public sector reform strategies. The first theme highlighted the importance of political economy dynamics, institutions and the incentives they create for the political and bureaucratic leadership groups who frame reform policies and implement them. The second theme emphasized leadership and change management: the need to mobilise individual and collective agency through building commitment, encouraging policy entrepreneurs and innovation and embedding ownership of reform on the ground. In response to the tendency of many developing countries to emulate superficially the organizational forms and processes of public sector organisations in advanced economies (“isomorphic mimicry") without substantively improving management performance, the third strand in the literature stressed the importance of public management function over mere form. A process of altering outward form, but not of underlying functionality is referred to as "institutional 
decoupling" (Andrews 2013). The final theme suggests that joint problem identification and consultation with a broad range of stakeholders during reform design and implementation, entrepreneurial experimentation, “learning by doing' in approached such as Problem Driven Iterative Adaption may significantly enhance the probability of reform success (Andrews 2013 and 2015, Cummings 2015).

The theme relating to leadership and change management is particular pertinent to public sector reform in South Africa. The National Development Plan 2030 has identified tensions in the political-administrative interface leading to high turnover of administrative leadership as one of the major factors contributing to the substantial variation in capacity across government departments, along with shortages of professional skills, attenuated accountability and ineffective organisational design. Increased politicisation of the recruitment of top management such as Directors General and Chief Financial Officers has led to pervasive instability in the politicaladministrative interface, especially in provincial governments:

At senior levels, reporting and recruitment structures have allowed for too much political interference in selecting and managing senior staff. The result has been unnecessary turbulence in senior posts, which has undermined the morale of public servants and citizens' confidence in the state (South Africa. National Planning Commission, 2012).

Reform implementation is a medium to long term enterprise, a protracted, evolving process rather than a single, defined event, unfolding in uncertain, complex, constantly changing implementation environments. Measurement of implementation processes poses an immense challenge (Pollit and Bouckaert, 2011, Gao, 2015), which would be 
further amplified by the emergent properties of more problem driven adaptive approaches (Brinkerhof and Brinkerhof, 2015). With few exceptions (such as Douglas, 2000; Andrews, 2013; Marti and Kasperskaya, 2015) empirical studies on public sector reforms have been predominantly qualitative. The majority of reform implementation studies have entailed fairly subjective assessments of outcomes relative to initial objectives (Rinnert, 2015). Comparisons of reform experiences within a particular country (across various provinces/states, municipalities or similar departments) controls for common policy design variables (e.g. a common legislative and policy frameworks) and thereby permits focussed scrutiny of reform implementation across comparable administrative contexts (Rinnert, 2015). In this vein, this paper fills a gap in the public administration literature by proposing a simple and easily updated and replicated but objective approach to tracking PFM reform implementation progress over time in a public sector organisation and benchmarking this progress against similar organisations, in order to identify and explain changes in implementation outcomes.

\section{APPROACHES TO EVALUATE THE IMPLEMENTATION OF PFM REFORM}

There are a host of reasons (theoretical, political and pragmatic) why rigorous evaluation of PFM reform seldom takes place. The aims and objectives of reforms are often vague, making evaluation of outcomes relative to initial objectives difficult. Reform objectives may themselves change over time at different phases over the reform trajectory (Jones and Kettl, 2003). Stakeholder perceptions on the motivation for reforms, their usefulness and results can vary significantly. Moreover there can be widely differing views on the criteria for measuring PFM implementation results and 
the objectives against which they are measured. For example, a study on the implementation of accrual accounting and output based budgeting in German municipalities found that the views of top managers of various municipalities differed markedly from middle management who actually implemented these reforms (Ridder $e t$ al., 2006).

Methodologically, there is no broadly accepted framework of analysis of PFM reform. A framework for evaluating public sector performance improvement requires a "theory of change" in order to structure the analysis (for example, to categorise reforms meaningfully), understand why certain reforms had their intended consequences (or did not), and be able to predict their anticipated impact. Boyne et al. (2003), for example, uses a public choice theoretical framework as a basis to evaluate public management reforms, predicated on the premise that increased competition, publication of performance information and disaggregation into smaller organizational units will lead to improved public service delivery efficiency and responsiveness to public demand. A common reform effectiveness analytical approach uses a logical framework approach which links resource inputs, the activities or processes which convert them to service delivery outputs and the direct and intermediate outcomes, and ultimately final impact. This approach is been considered simplistic, and overly linear and rational in relation to PFM reform. While it does provide an analytical framework, it still needs to be supplemented by a "theory of change" in order to enable rigorous evaluation of its application (Pollitt and Boukaert, 2011).

Attribution challenges arise in providing systematic evidence of causation between a particular PFM reform's intent, its implementation and any subsequent change in government service delivery or financial performance (Goldfinch et al., 2013). Reform 
programmes typically combine new PFM approaches with mutually reinforcing innovations in, inter alia, human resource management, monitoring and evaluation. Therefore, it is difficult to isolate the effect of a single reform intervention.

There may be strong political motivations for discouraging rigorous evaluation of PFM reform outcomes. An unfavourable public evaluation of a reform effort would be a political indictment on the politicians initiating them. PFM reform announcements may be little more than political gambits with limited political will to actually implement them, merely symbolic devices centring around "adopting and adapting fashionable rhetoric" while "things continue much as before", especially when access to foreign aid or loans is at stake (Goldfinch et al., 2013: 54). Where a new organization has been created or a function shifted to enable reform, the step could be politically irreversible with little likelihood that a negative evaluation could prompt a reversion to the previous status quo. Finally, in a volatile political reform environment, even if an evaluation of PFM reforms is initiated, the policy focus could move to the next reform "flavour of the month".

While evidence-based evaluation techniques can assist in the systematic evaluation of the success or failure of PFM reforms, all impact evaluation techniques are, however, subject to certain methodological or data limitations in their application. An assessment of the benefits and (often unintended) negative consequences resulting from reform, relative to the resources consumed during the reformation phase, inevitably entails some degree of subjectivity. Since they entail value judgements, assessments of PFM impacts are thus "ultimately, inherently and inescapably political" (Boyne et al., 2003:157). 
Baseline indicators are often not collected to establish the status quo before the reform programme. This could be as a result of a delay in initiating evaluations to capture the relevant information. In South Africa, comprehensive financial and non-financial (performance) baseline information was not collected from the provincial government departments prior to the PFMA reforms of 1999.

The implementation of reform plans may not be well-documented. While it is fairly easy to monitor the initiation of reforms through desktop research, assessing the extent to which policy intent is translated into changed operational practices is complicated and expensive requiring extensive fieldwork. To evaluate unambiguously whether changed PFM improved fiscal and service delivery outcomes is even more complex and costly, particularly in developing countries. Particular PFM targets may be met, but with unintended consequences. For example, quantity targets may be met but quality is compromised or short term objectives may be achieved at the expense of long term performance (Pollitt and Boukaert, 2011). Where evaluations of PFM reforms have been done, they were often performed by originators or advocates of reform themselves, casting doubt on their objectivity (Newbery and Pallot, 2005).

Another challenge faced by researchers investigating PFM reform is the explosion of jargon entering the professional lexicon as a result of New Public Management (NPM) and other recent conceptual frameworks: performance indicators, the purchaser-provider split, accrual accounting, devolved budgets, budget institutions, performance budgeting etc. Often the same concept is known by different names in different countries (e.g. performance budgeting, results based budgeting and output based budgeting which are essentially the same thing). Even when countries adopt a similar terminology for reform 
instruments or management approaches, the way these are practically applied across country contexts can vary markedly (Guthrie et al., 1999).

While more evaluation is needed, there is also the danger of excessive evaluation, where more time and resources are spent on "checking" rather than "doing" the actually delivering public goods and services (Gray and Jenkins, 2004). Guthrie et al. (1999) warn of a potential "evaluation trap". In the quest to enhance performance, increased monitoring and auditing may be done, but this in turn raises the indirect cost of service delivery. Periods of fiscal stress may create pressure to effect budget cuts. Auditing and evaluation expenditure could however be protected in the name of compliance, legitimacy and good governance, with cuts disproportionately focused on core service delivery. The increased indirect cost per unit of service could lead to a decrease in access or quality of services, which in turn may stimulate calls for even more evaluation and auditing.

The Public Expenditure and Financial Accountability (PEFA) indicator set was developed by a multi-donor group in 2005 to assess progress with PFM reforms. The 28 indicators in the PEFA framework are structured into four categories:

1. PFM system outcomes, such as deviations of the executed budget from the appropriated budget and the level of arrears;

2. cross-cutting features of the system, such as basic transparency and comprehensiveness of the budget, public access to budget information;

3. budget-cycle performance covering formulation (orderliness and participation in the annual budget process, whether there is a multi-year budget perspective); budget 
execution (predictability, recording, control), accounting and reporting, external scrutiny and audit;

4. donor practices and how these influence the performance of country PFM system (PEFA, 2006:3).

Seventy countries now apply the PEFA indicators, but only a much smaller sub-set makes their assessments publicly available (on the www.pefa.org) and there is variation in the quality of indicators across countries (Overseas Development Institute, 2007).

The PEFA approach has many advantages. It conceives of the PFM as a system comprising inter-related processes which cumulatively generate PFM outcomes, within a theoretical model explaining why certain combinations of processes can lead to certain outcomes. Despite quite extensive coverage of PFM process areas, the set of 28 indicators is fairly concise. By being high-level the indicators strike a balance between standardisation and permitting variation in the detail. The assessments themselves are fairly simple and amenable to evidence-based analysis. Finally, governments who score poorly in certain areas gain insight into how they can improve (Andrews 2007; Boulding et al., 2012).

The PEFA indicator set is, however, subject to some limitations. PEFA indicators cover most process areas, but not all of them (such as policy development). PFM effectiveness can, in the final analysis, only be evaluated relative to the goals of a particular PFM system which differ across countries and may not be conducive to standardisation. Finally, indicator sets such as PEFA may be too static and addresses only elementary levels of PFM development (Andrews, 2007). But its biggest shortcoming in relation to developing countries is that its focus is limited to the 
technical dimensions of PFM reform, largely ignoring the context-specific institutional dynamics of budget systems. Critics have contended that the PEFA indicator set, therefore, "implicitly incorporates a value system that is based on the practices of developed economies" resulting in inadequate and possibly distorted diagnostic on the basis of which to develop an action plan for PFM reform (Allen, 2009:14). The governments of some countries have regarded PEFA assessments as a donor-driven exercise with little host country “ownership”. Many governments undergoing PEFA assessments have elected not to make the resulting reports public, precluding dialogue with civil society on PFM reform issues.

In countries where significant fiscal powers have been devolved to subnational governments such as South Africa, the PEFA indicator set's exclusive focus on central governments may be a serious shortcoming. In the context of fiscal risk management in China, for instance, the exclusion of subnational governments from Chinese PEFA studies systematically under-estimates the assessment of the country's fiduciary risk (Guess and Ma, 2015). A publicly available PEFA assessment was conducted for the South African national government in 2008, but the methodology was not applied to provincial governments. The national government scored well in terms of budget credibility, comprehensiveness, transparency, policy-based budgeting within a medium term framework, predictability and control in budget execution. Areas for improvement related to the lack of integration of state owned public enterprises with the budget system and in relation to supply chain management (Quist et al., 2008)

A fruitful line for further research relates to the fact that even within particular countries, certain institutions or groups of institutions perform better than their peers, so called "reform enclaves". Understanding systematically how these "reform enclaves" 
develop and identifying their underlying performance drivers could support replication of their success (Allen, 2006). This study of PFM progress contributes to this understanding by assessing progress with PFM reform implementation to date in the nine provincial PEDs in South Africa and the factors which have encouraged or undermined the reform implementation trajectory in each PED. By focussing on the impact of leadership by Chief Financial Officers (CFOs) and Accounting Officers (AOs) and the effectiveness of governance structures as well the more technical elements of PFM reform, the study contributes to filling a gap on the developing country PFM reform literature which has tended to focus predominantly on the reconfiguration of formal institutions, and virtually ignored the interplay with more informal, but equally critical, institutions such as leadership.

\section{THE INSTITUTIONAL CONTEXT OF REFORMS IN PEDS}

\section{The role of provincial government in South Africa}

The Constitution of the Republic of South Africa, 1996, which heralded a transition from the apartheid regime to a democratic order, established three spheres of government (national, provincial and local). Nine provincial governments were established, replacing the previous four provincial administrations of "White" South Africa and the plethora of so-called "independent states" and "homelands" create for Blacks. Most of the buoyant taxes are centralised in the national sphere (e.g. personal income tax, corporate income tax, and Value Added Tax). Provincial governments have very few "own revenue" sources but are reliant on unconditional intergovernmental grants (the Equitable Share Grant) and conditional grants from the national government. Provincial governments do, however, have considerable expenditure responsibilities, 
especially in concurrent functions such as basic education and health which are shared between the national and provincial spheres. National sector departments (such as the national Departments of Basic Education and of Health), formulate policies which are implemented by their provincial department counterparts and funded from the province's Equitable Share grants. Provincial Executive Councils determine how much of their Equitable Share and other revenue sources they will allocate to basic education as opposed to other provincial functions such as health, provincial roads, agriculture (Black et al., 2003).

Basic education is highly labour intensive. The budget for compensation of employees accounts on average for approximately 79 percent of the total education expenditure across the nine provinces (South Africa. National Treasury, 2015). Conditions of services (such as salaries) are, however, determined at the national sphere through collective bargaining. PED personnel budgets are rigid and can influence personnel budgets primarily through increasing or decreasing the number of employees (i.e employee headcount). This is difficult in the short term given the complex labour legislation and the politically powerful, militant teacher unions. In 2007, the Occupation Specific Dispensation (OSD) was introduced by the national government, aimed to provide differentiated salary structures in specific occupations with scarce skills in order to enhance public sector recruitment and retention. The objective was to implement OSD for educators, doctors, nurses, and professionals in various categories. However, different provinces applied different criteria in implementing the OSD. Often, the OSD was not implemented as originally intended but more as an across the board increase, also fuelling personnel spending pressures in provincial departments such as education (Madabula and Dawood, 2013). 
Table 1. Selected public ordinary schooling indicators by provincial education department, 2013

\begin{tabular}{|c|c|c|c|c|c|c|c|c|c|c|c|}
\hline & $\begin{array}{l}\text { No of } \\
\text { learners } \\
\text { (in } \\
1000 \mathrm{~s})\end{array}$ & $\begin{array}{l}\text { As a } \% \\
\text { of } \\
\text { national } \\
\text { total }\end{array}$ & $\begin{array}{c}\text { No of } \\
\text { educators } \\
\text { (in } \\
1000 \mathrm{~s} \text { ) }\end{array}$ & $\begin{array}{l}\text { As a } \% \\
\text { of } \\
\text { national } \\
\text { total }\end{array}$ & $\begin{array}{c}\text { No of } \\
\text { public } \\
\text { ordinary } \\
\text { schools }\end{array}$ & $\begin{array}{l}\text { As a } \% \\
\text { of } \\
\text { national } \\
\text { total }\end{array}$ & $\begin{array}{c}\text { Average } \\
\text { spending } \\
\text { per } \\
\text { learner in } \\
\text { Rand } \\
(2013 / 14)\end{array}$ & $\begin{array}{l}\% \\
\text { variance } \\
\text { from the } \\
\text { national } \\
\text { average }\end{array}$ & $\begin{array}{l}\text { National } \\
\text { Senior } \\
\text { Certificate } \\
\text { Pass rate }\end{array}$ & $\begin{array}{c}\text { National } \\
\text { Senior } \\
\text { Certificate } \\
\text { Batchelor's } \\
\text { pass rate }\end{array}$ & $\begin{array}{c}\text { Poverty } \\
\text { head- } \\
\text { count }\end{array}$ \\
\hline Eastern Cape & 1882 & 15.7 & 63 & 16.1 & 5562 & 23.04 & R 14232 & $-1 \%$ & 64.9 & 19.0 & 60.8 \\
\hline Free State & 650 & 5.4 & 24 & 6.1 & 1327 & 5.50 & R 16247 & $13 \%$ & 87.4 & 33.1 & 41.2 \\
\hline Gauteng & 1900 & 15.9 & 59 & 15.1 & 2056 & 8.52 & R 15377 & $7 \%$ & 87.0 & 38.9 & 22.9 \\
\hline KwaZulu-Natal & 2799 & 23.4 & 91 & 23.3 & 5937 & 24.60 & R 13275 & $-8 \%$ & 77.4 & 32.5 & 56.6 \\
\hline Limpopo & 1662 & 13.9 & 55 & 14.0 & 3924 & 16.26 & R 13626 & $-5 \%$ & 71.8 & 22.8 & 63.8 \\
\hline Mpumalanga & 1026 & 8.6 & 33 & 8.5 & 1768 & 7.33 & R 14284 & $-1 \%$ & 77.6 & 25.9 & 52.1 \\
\hline Northern Cape & 279 & 2.3 & 9 & 2.2 & 553 & 2.29 & R 16066 & $12 \%$ & 87.2 & 34.9 & 46.8 \\
\hline North West & 773 & 6.5 & 25 & 6.4 & 1551 & 6.43 & R 15090 & $5 \%$ & 74.5 & 23.3 & 50.5 \\
\hline Western Cape & 1005 & 8.4 & 32 & 8.3 & 1458 & 6.04 & R 15029 & $4 \%$ & 85.1 & 40.9 & 24.7 \\
\hline National & 11976 & 100.0 & 392 & 100.0 & 24136 & 100.0 & R 14385 & & 78.2 & 30.6 & 45.5 \\
\hline
\end{tabular}

Data refer specifically to ordinary public schools. . Public schools for learners with special needs, early childhood development site, adult learning centres etc. are excluded.

Average per learner spending was calculated using audited actual spending from the National Treasury database divided by the number of learners per province.

Poverty headcount: This is the share of the provincial population whose income or consumption is below the poverty line of R620 per month in 2011.

Sources: Department of Basic Education, 2013, National Treasury database, Statistics South Africa, 2014. 
Table 1 illustrates the considerable variation among PEDs in terms of the number of learners, schools and teachers, pass rates for the senior certificate examinations and Batchelor's which permit entry to university and provincial poverty rates. Rural provinces with high rates of poverty (such as the Eastern Cape, Limpopo and KwaZuluNatal Provinces) tend to have larger numbers of learners and teachers, more schools but poor pass rates, especially, the Batchelor's rate (which permits entry into university and is crude measure of education quality). Average spending levels per learner also tend to be lower than the national average.

\section{The Public Finance Management Act of 1999 (PFMA)}

The PFMA which came into effect on 1 April 2000 aimed to modernise PFM and "secure accountability and sound management of revenue, expenditure, assets and liabilities" of national and provincial organs of state". The PFMA was the cornerstone of the South African Government's budget and financial management reform agenda. Earlier reforms undertaken since 1994 such as tax reforms and the medium term expenditure framework had aimed to enhance macroeconomic stability and aggregate fiscal discipline. However, the PFMA also emphasises operational efficiency and value for money. The PFMA represents a radical departure from prescriptive, detailed Exchequer Acts of the past which were concerned mainly with procedural accountability for finances (e.g., were the correct authorisation procedures for a financial transaction followed?). The PFMA placed greater emphasis on accountability for results (i.e. service delivery outputs and outcomes) and essentially situated PFM within an institutional performance management framework. Inspired by international NPM approaches, the PFMA envisaged moving from a highly centralized input-oriented 
expenditure control system towards a more performance oriented system that would "allow managers to manage but hold them accountable" (Folscher and Cole, 2006).

The PFMA and its regulations introduced a number of reforms, inter alia, relating to integrating planning and budgeting through greater use of performance information, regular monthly reporting of financial outcomes and quarterly reporting of actual performance vis-à-vis targets, cash management, supply chain and asset management reforms, accounting reforms from a pure cash accounting system to a modified system as a springboard to amore accruals based accounting system. The Public Audit Act of 2004 also enabled the Auditor-General of South Africa to audit performance information submitted by national and provincial departments as well as conventional financial and compliance audits (Wildeman and Jogo, 2012).

\section{DATA AND METHODOLOGY}

\section{Variables and data sources}

As part of a broader doctoral study (Ajam, 2016), a Public Financial Management Progress (PFMP) index was constructed as a quantitative analytical tool to assess the progress of PFM reform in PEDs, based on publicly available financial information between 2007/08 and 2013/14 from the nine PEDs' Annual Performance Plans, budgets, Annual Reports (as collated electronically in the National Treasury database) and audited Annual Financial Statements (from successive annual Auditor General Reports).

The PFMP index enables the comparison of financial management quality in a particular PED department over a period of time to assess its progress, and compared to other PEDs in a benchmarking exercise. This was the only period for which a complete 
set of data was available. Audits of performance information (known as Audits of Predetermined Objectives in South Africa) by the Auditor-General in terms of the Public Audit Act, 2004 was phased-in after the National Treasury released its Framework for Managing Performance Information in 2007. For the period 1994 to 2007, only financial audit outcomes were available.

Table 2 delineates the definitions of the nine variables comprising the PFMP index, what they attempted to measure, how they were ranked and the relevant sources of data. Unlike the more comprehensive but time-consuming PEFA assessments which are expensive to replicate frequently and require access to information that is generally not in the public domain, the annual publication of these source documents that the PFMP index can be easily updated and also applied to all other provincial departments such as health, agriculture or provincial roads.

The nine indicators underlying the PFMP index are proxies for the PFM functions performed by departmental PFM systems and the effectiveness of financial leadership and governance as assessed annually by the Auditor-General. As illustrated in Table 2, the four indicators relate to budget planning and expenditure controls for the personnel, goods and services, transfers and capital budgets of PEDs. Two indicators relate to supply chain management as part of budget execution. A further two indicators capture financial and non-financial (performance information) reporting while the final one relates to financial leadership and governance.

\section{Sample and methodology}

PEDs were selected as objects of this study not only because of their high policy but also because they are the single largest spending agencies in the provincial sphere, 
Table 2. Definition of PFMP index variables, variable ranking and data sources

\begin{tabular}{|c|c|c|c|c|c|}
\hline & $\begin{array}{c}\text { INDICATOR } \\
\text { NAME }\end{array}$ & DESCRIPTION OF VARIABLE & PROXY MEASURE FOR & INDEX RATING & $\begin{array}{c}\text { DATA } \\
\text { SOURCE }\end{array}$ \\
\hline 1 & $\begin{array}{l}\text { Compensation } \\
\text { of Employees } \\
\text { budget } \\
\text { deviation }\end{array}$ & $\begin{array}{l}\text { Difference between the budgeted and } \\
\text { actual expenditure on Compensation } \\
\text { of Employees as at year end as a } \\
\text { percentage of final appropriation } \\
\text { expenditure compensation allocation. } \\
\text { Compensation of employees is } \\
\text { defined in the Standard Chart of } \\
\text { Accounts as all current personnel- } \\
\text { related payments - all payments to } \\
\text { government employees, both salaries } \\
\text { and wages and social contributions. } \\
\text { Social contributions are service } \\
\text { benefits paid by government for its } \\
\text { employees, such as pension or } \\
\text { medical scheme contributions. }\end{array}$ & $\begin{array}{l}\text { Percentage over or under- } \\
\text { spending of the } \\
\text { Compensation of Employees } \\
\text { budget proxies for the } \\
\text { effectiveness of Human } \\
\text { Resources budget planning } \\
\text { and payroll management. } \\
\text { Poor personnel budget } \\
\text { control and consequent } \\
\text { overspending crowds out } \\
\text { complementary inputs such } \\
\text { as school text books or } \\
\text { stationery. }\end{array}$ & $\begin{array}{l}5 \text { - Over/underspending } \\
\text { of less than } 5 \% \text {, } \\
4 \text { - Over/underspending } \\
\text { of } 5 \text { to less than } 10 \% \\
3 \text { - Over/underspending } \\
\text { of } 10 \% \text { to less than } 15 \% \\
2 \text { - Over/underspending } \\
\text { of } 15 \% \text { to less than } 25 \% \\
\text { 1- Over/underspending } \\
\text { of between } 25 \text { and } 50 \% \\
0 \text { - Over/underspending } \\
\text { of more than } 50 \%\end{array}$ & $\begin{array}{l}\text { Annual } \\
\text { Financial } \\
\text { Statements } \\
\text { (National } \\
\text { Treasury } \\
\text { database) }\end{array}$ \\
\hline 2 & $\begin{array}{l}\text { Goods and } \\
\text { services } \\
\text { budget } \\
\text { deviation }\end{array}$ & $\begin{array}{l}\text { Difference between the budgeted and } \\
\text { actual expenditure on goods and } \\
\text { services as at year end as a percentage } \\
\text { of final appropriation goods and } \\
\text { services allocation. This } \\
\text { encompasses all government } \\
\text { payments in exchange for goods and } \\
\text { services, but excludes capital assets } \\
\text { and goods used by government for } \\
\text { construction of and improvements to }\end{array}$ & $\begin{array}{l}\text { Percentage over or under- } \\
\text { spending of the goods and } \\
\text { services budget is a proxy } \\
\text { for the effectiveness of } \\
\text { operational planning and } \\
\text { supply chain management } \\
\text { processes }\end{array}$ & $\begin{array}{l}5 \text { - Over/underspending } \\
\text { of less than } 5 \% \text {, } \\
4 \text { - Over/underspending } \\
\text { of } 5 \text { to less than } 10 \% \\
3 \text { - Over/underspending } \\
\text { of } 10 \% \text { to less than } 15 \% \\
2 \text { - Over/underspending } \\
\text { of } 15 \% \text { to less than } 25 \% \\
1-\text { Over/underspending } \\
\text { of between } 25 \text { and } 50 \%\end{array}$ & $\begin{array}{l}\text { Annual } \\
\text { Financial } \\
\text { Statements } \\
\text { (National } \\
\text { Treasury } \\
\text { database) }\end{array}$ \\
\hline
\end{tabular}




\begin{tabular}{|c|c|c|c|c|c|}
\hline & $\begin{array}{l}\text { INDICATOR } \\
\text { NAME }\end{array}$ & DESCRIPTION OF VARIABLE & PROXY MEASURE FOR & INDEX RATING & $\begin{array}{l}\text { DATA } \\
\text { SOURCE }\end{array}$ \\
\hline & & capital assets. & & $\begin{array}{l}0 \text { - Over/underspending } \\
\text { of more than } 50 \%\end{array}$ & \\
\hline 3 & $\begin{array}{l}\text { Transfer } \\
\text { budget } \\
\text { deviation }\end{array}$ & $\begin{array}{l}\text { Difference between the budgeted and } \\
\text { actual expenditure on transfers and } \\
\text { subsidies, as a percentage of final } \\
\text { appropriation transfer allocation. } \\
\text { This category encompasses funds that } \\
\text { are transferred to (and spent by) other } \\
\text { institutions (such as independent } \\
\text { schools and non-profit organisations), } \\
\text { businesses and individuals, and are } \\
\text { not spent by the department itself. }\end{array}$ & $\begin{array}{l}\text { This allows for the } \\
\text { separation of all transfers } \\
\text { from payments } \\
\text { controlled directly by } \\
\text { departments. Percentage } \\
\text { over or under-spending of } \\
\text { the transfers budget is a } \\
\text { proxy for the efficiency with } \\
\text { which departmental } \\
\text { administrative systems can } \\
\text { identify, verify and pay over } \\
\text { transfers (e.g. subsidies to } \\
\text { independent schools ). }\end{array}$ & $\begin{array}{l}5 \text { - Over/underspending } \\
\text { of less than } 5 \% \text {, } \\
4 \text { - Over/underspending } \\
\text { of } 5 \text { to less than } 10 \% \\
3 \text { - Over/underspending } \\
\text { of } 10 \% \text { to less than } 15 \% \\
2 \text { - Over/underspending } \\
\text { of } 15 \% \text { to less than } 25 \% \\
1-\text { Over/underspending } \\
\text { of between } 25 \text { and } 50 \% \\
0 \text { - Over/underspending } \\
\text { of more than } 50 \%\end{array}$ & $\begin{array}{l}\text { Annual } \\
\text { Financial } \\
\text { Statements } \\
\text { (National } \\
\text { Treasury } \\
\text { database) }\end{array}$ \\
\hline 4 & $\begin{array}{l}\text { Capital budget } \\
\text { deviation }\end{array}$ & $\begin{array}{l}\text { Difference between the budgeted and } \\
\text { actual expenditure on capital, as a } \\
\text { percentage of final appropriation } \\
\text { capital allocation. The capital budget } \\
\text { covers purchases of new assets, as } \\
\text { well as upgrades, additions, } \\
\text { rehabilitation and refurbishment of } \\
\text { existing assets. }\end{array}$ & $\begin{array}{l}\text { Percentage over or under- } \\
\text { spending of the capital } \\
\text { budget shows the } \\
\text { effectiveness of } \\
\text { departmental infrastructure } \\
\text { management and the } \\
\text { extension of access to } \\
\text { services (e.g. through new } \\
\text { schools). }\end{array}$ & $\begin{array}{l}5 \text { - Over/underspending } \\
\text { of less than } 5 \% \text {, } \\
4 \text { - Over/underspending } \\
\text { of } 5 \text { to less than } 10 \% \\
3 \text { - Over/underspending } \\
\text { of } 10 \% \text { to less than } 15 \% \\
2 \text { - Over/underspending } \\
\text { of } 15 \% \text { to less than } 25 \% \\
1 \text { - Over/underspending } \\
\text { of between } 25 \text { and } 50 \% \\
0 \text { - Over/underspending } \\
\text { of more than } 50 \%\end{array}$ & $\begin{array}{l}\text { Annual } \\
\text { Financial } \\
\text { Statements } \\
\text { (National } \\
\text { Treasury } \\
\text { database) }\end{array}$ \\
\hline
\end{tabular}




\begin{tabular}{|c|c|c|c|c|c|}
\hline & $\begin{array}{l}\text { INDICATOR } \\
\text { NAME }\end{array}$ & DESCRIPTION OF VARIABLE & PROXY MEASURE FOR & INDEX RATING & $\begin{array}{c}\text { DATA } \\
\text { SOURCE }\end{array}$ \\
\hline 5 & $\begin{array}{l}\text { Financial } \\
\text { audit } \\
\text { outcomes }\end{array}$ & $\begin{array}{l}\text { Financial audit opinion expressed in } \\
\text { the annual financial statements by the } \\
\text { auditor general on the whether they } \\
\text { are a fair representation of the } \\
\text { financial status of a department or } \\
\text { public entity }\end{array}$ & $\begin{array}{l}\text { Quality of financial } \\
\text { statements and effectiveness } \\
\text { of financial controls }\end{array}$ & $\begin{array}{l}4 \text { - Financially } \\
\text { unqualified } \\
3 \text { - Financially } \\
\text { unqualified with findings } \\
2 \text { - Qualified } \\
1 \text { - Adverse or } \\
\text { Disclaimer } \\
0 \text { - Not submitted by due } \\
\text { date }\end{array}$ & $\begin{array}{l}\text { Auditor } \\
\text { General } \\
\text { Consolidated } \\
\text { General } \\
\text { Report on } \\
\text { National and } \\
\text { Provincial } \\
\text { Audit } \\
\text { Outcomes }\end{array}$ \\
\hline 6 & $\begin{array}{l}\text { Audit of } \\
\text { Predetermined } \\
\text { Objectives } \\
\text { (AOPO) } \\
\text { outcomes }\end{array}$ & $\begin{array}{l}\text { Auditees are required by the PFMA to } \\
\text { report on their actual performance } \\
\text { against predetermined performance } \\
\text { objectives in their Annual } \\
\text { Performance Plans. The Auditor } \\
\text { General determines whether the } \\
\text { reported performance against } \\
\text { auditees' predetermined objectives is } \\
\text { useful and reliable in all respects }\end{array}$ & $\begin{array}{l}\text { Quality of non-financial } \\
\text { reporting, the integration of } \\
\text { plans with budgets, progress } \\
\text { in implementing } \\
\text { performance budgeting }\end{array}$ & $\begin{array}{l}1 \text { point each for (a) } \\
\text { compliance with } \\
\text { regulations, (b) } \\
\text { usefulness, (c) reliability } \\
\text { and (d) submission } \\
\text { timeliness. Maximum } \\
\text { score is } 4 \text { points for a } \\
\text { department with no } \\
\text { AOPO findings. }\end{array}$ & $\begin{array}{l}\text { Auditor } \\
\text { General } \\
\text { Consolidated } \\
\text { General } \\
\text { Report on } \\
\text { National and } \\
\text { Provincial } \\
\text { Audit } \\
\text { Outcomes }\end{array}$ \\
\hline 7 & $\begin{array}{l}\text { Irregular } \\
\text { expenditure } \\
\text { ( } \mathrm{R} \text { millions) }\end{array}$ & $\begin{array}{l}\text { Expenditure incurred without } \\
\text { complying with the applicable } \\
\text { legislation, mainly procurement } \\
\text { regulations in terms of the PFMA but } \\
\text { also compensating employees in } \\
\text { terms of the Public Service Act. }\end{array}$ & $\begin{array}{l}\text { Effectiveness of supply } \\
\text { chain management and } \\
\text { payroll systems compliance }\end{array}$ & $\begin{array}{l}5 \text { - No irregular } \\
\text { expenditure } \\
4 \text { - less than R50 million } \\
3 \text { - between R50 and } \\
\text { R100 million } \\
2 \text { - between R100 and } \\
\text { R250 million } \\
1 \text { - between R250 and } \\
\text { R500 million } \\
0 \text { - above R500 million }\end{array}$ & $\begin{array}{l}\text { Auditor } \\
\text { General } \\
\text { Consolidated } \\
\text { General } \\
\text { Report on } \\
\text { National and } \\
\text { Provincial } \\
\text { Audit } \\
\text { Outcomes }\end{array}$ \\
\hline
\end{tabular}




\begin{tabular}{|c|c|c|c|c|c|}
\hline & $\begin{array}{l}\text { INDICATOR } \\
\text { NAME }\end{array}$ & DESCRIPTION OF VARIABLE & PROXY MEASURE FOR & INDEX RATING & $\begin{array}{c}\text { DATA } \\
\text { SOURCE }\end{array}$ \\
\hline 8 & $\begin{array}{l}\text { Fruitless and } \\
\text { wasteful } \\
\text { expenditure } \\
\text { (R millions) }\end{array}$ & $\begin{array}{l}\text { Expenditure which was made in vain } \\
\text { and could have been avoided had } \\
\text { reasonable care been taken. This } \\
\text { includes penalties and interest on late } \\
\text { payments as well as payment for } \\
\text { services not utilised or goods not } \\
\text { received. }\end{array}$ & $\begin{array}{l}\text { Indicator of value for money } \\
\text { and operational efficiency }\end{array}$ & $\begin{array}{l}5 \text { - No irregular } \\
\text { expenditure } \\
4 \text { - less than R50 million } \\
3 \text { - between R50 and } \\
\text { R100 million } \\
2 \text { - between R100 and } \\
\text { R250 million } \\
1 \text { - between R250 and } \\
\text { R500 million } \\
0 \text { - above R500 million }\end{array}$ & $\begin{array}{l}\text { Auditor } \\
\text { General } \\
\text { Consolidated } \\
\text { General } \\
\text { Report on } \\
\text { National and } \\
\text { Provincial } \\
\text { Audit } \\
\text { Outcomes }\end{array}$ \\
\hline 9 & $\begin{array}{l}\text { Leadership, } \\
\text { governance } \\
\text { and financial } \\
\text { and } \\
\text { performance } \\
\text { management } \\
\text { findings } \\
\text { (drivers of } \\
\text { internal } \\
\text { control) }\end{array}$ & $\begin{array}{l}\text { The Auditor General annually } \\
\text { evaluates } 3 \text { overall drivers of internal } \\
\text { control required for good audit } \\
\text { outcomes: } \\
\text { (a) Whether Accounting officers, } \\
\text { MECs and senior management have } \\
\text { discharged their statutory PFMA } \\
\text { responsibilities } \\
\text { (b) The effectiveness of governance } \\
\text { structures (e.g. audit committees) and } \\
\text { processes (internal audit and risk } \\
\text { management) of the auditee and } \\
\text { (c) The management of resources to } \\
\text { achieve the financial and service } \\
\text { delivery objectives of the auditee (e.g. } \\
\text { controls over processing transactions } \\
\text { and reconciliations, regular financial } \\
\text { and performance reports and }\end{array}$ & $\begin{array}{l}\text { Underlying drivers of } \\
\text { internal controls, effectives } \\
\text { of management and } \\
\text { institutional capability }\end{array}$ & $\begin{array}{l}\text { An auditee with no } \\
\text { leadership, governance } \\
\text { or financial management } \\
\text { and performance } \\
\text { management findings by } \\
\text { the AG would receive } 3 \\
\text { points. If there are } \\
\text { leadership, governance, } \\
\text { or financial and } \\
\text { performance } \\
\text { management findings } \\
\text { then a point is subtracted } \\
\text { for each category of } \\
\text { finding. }\end{array}$ & $\begin{array}{l}\text { Auditor } \\
\text { General } \\
\text { Consolidated } \\
\text { General } \\
\text { Report on } \\
\text { National and } \\
\text { Provincial } \\
\text { Audit } \\
\text { Outcomes }\end{array}$ \\
\hline
\end{tabular}




\begin{tabular}{|l|l|l|l|l}
\hline $\begin{array}{c}\text { INDICATOR } \\
\text { NAME }\end{array}$ & DESCRIPTION OF VARIABLE & PROXY MEASURE FOR & INDEX RATING DATA \\
\hline & $\begin{array}{l}\text { monitoring of compliance with } \\
\text { regulations) }\end{array}$ & & \\
\hline
\end{tabular}

Note: All Standard Chart of Account definitions cited verbatim from Annexure W2 of the 2013 Budget Review $\quad$ (South Africa. National Treasury, 2013a). All auditing terms extracted verbatim from the Glossary of Terms, Acronyms and Abbreviations, 2012-13 Consolidated General Report on the national and provincial audit outcomes (South Africa. Auditor General, 2013a:279-285). 
collectively comprising just over $40 \%$ of the aggregate provincial expenditure in 2014/15 (South Africa. National Treasury, 2015).

The PFMP index is a weighted average of a set of nine indicators of public financial management practice from 2007/8 to 2012/14. For each PED in every fiscal year, the outcome of the nine indicators is scored (generally on a scale from 0 to 5 as reflected in Table 2, where 0 is the worst possible performance and 5 is the best). For example, where budgets for compensation of employees in a particular department was over- or under-spent in a particular year by $5 \%$ of the total departmental expenditure or less, a score of 5 was assigned, whereas if over- or underspending was between 15 and 25 percent of the total expenditure, a score of 3 was assigned, and so forth.

To calculate a weighted average, each of the indicators is then assigned a weight of 10 percent, except the financial audit outcomes which is weighted at 20 percent because of the emphasis on policy by the National Treasury and the Auditor-General on "clean audit outcomes". As noted by Guess and Ma (2015), the transparent disclosure of the underlying index variables and their weights fosters greater rigour and replicability and reduces subjectivity of the final aggregate scores.

A "clean audit" refers to an opinion in which: (a) the financial statements are unqualified (i.e. contain no material misstatements), (b) the audit of predetermined objectives (AOPO) has no material findings related to performance information and (c) there are no other findings related to non-compliance with legislation such as the PFMA or the Public Service Act of 1994 (South Africa. Auditor-General, 2013: 280).

In order to reflect the quality of PFM practice in a department, it is appropriate that the PFMP index contain not only financial outcome indicators, but also those relating to 
performance information and other forms of compliance (such as supply chain management and payroll controls). Effective financial governance institutions (e.g. audit committees and internal audit functions) as well as more informal yet powerful institutions such as leadership by heads of department as AOs, CFOs and provincial Members of the Executive Council (MECs) are also critical. Moreover, a variable is also included in the PFMP index to capture financial leadership and governance findings by the Auditor-General. Marti and Kasperskaya (2015) observe that, while a plethora governance indicators have been generated, there are still no generally accepted criteria for what constitutes good governance. The use of the Auditor-General's financial leadership and governance variable in the PFMP index is compelling because it is produced annually by an independent supreme audit institution, it is applied uniformly across all national and provincial government departments in South Africa, and is underpinned by international auditing standards and statutory requirements of the PFMA.

The PFMP index comprises the sum of each of the nine weighted indicators. The lowest possible score a provincial department may achieve on the PFMP index in any given year is 0 and the maximum possible score is 4.5 .

To identify the underlying root causes driving PFMP index results, the AuditorGeneral's audit report on the annual financial statements and the annual report was analysed for each PED between 2007/8 to 2012/14. To further validate these findings, interviews were conducted with 10 officials from the National Treasury, 11 officials from seven of the nine provincial treasuries who agreed to participate in this study, and two knowledgeable independent experts (from academia and the Financial and Fiscal Commission of South Africa). 


\section{ANALYSIS OF RESULTS}

Table 3 depicts the PFMP index score for each of the nine PEDs for the period 2007/08 to $2013 / 14$. The table also reflects the average PFMP index score between $2007 / 08$ and 2009/10 and between 2009/10 and 2013/14 which enables the comparison of the average performance of each PED across these two periods. The penultimate column of Table 3 shows the difference in average scores across these two periods (with a negative score indicating deterioration in contrast to a positive score indicating progress). The final column of the table lists the PFMP index score each department had achieved in 2013/14 as a percentage of the maximum possible score (out of 4.5), a simple measure of PFM progress.

During the period under analysis, PFM in PEDs appear to have regressed marginally or stagnated at best. The average PFMP index score for all the nine provinces was 3.3 points between 2007/08 and 2009/10 but it declined marginally to an average of 3.2 points in the successive period from 2010/11 to $2013 / 14$.

There was considerable variation in PFMP index scores across the nine PEDs. In both periods, the Eastern Cape PED demonstrated the worst performance with an average PFMP index score of 2.4 points between 2007/08 and 2009/10 and between 2010/11 to 2013/14 (far below the national averages of 3.3 and 3.2 in those periods respectively). This PED displayed chronically poor PFM performance, achieving a PFMP Index in 2013/14 of 52 percent of the maximum achievable score of 4.5 .

Another department which serially and materially under-performed on the national average in these two periods was Limpopo PED. This department displayed a marked deterioration from an average PFMP index score of 3.4 between 2007/08 and 2009/10 
Table 3. Provincial education department PFMP Index, 2007/08 to 2013/14

\begin{tabular}{|l|l|l|l|l|l|l|l|l|l|l|c|}
\hline PFMP INDEX & $\mathbf{2 0 0 7 / 8}$ & $\mathbf{2 0 0 8 / 9}$ & $\mathbf{2 0 0 9 / 1 0}$ & $\mathbf{2 0 1 0 / 1 1}$ & $\mathbf{2 0 1 1 / 1 2}$ & $\mathbf{2 0 1 2 / 1 3}$ & $\mathbf{2 0 1 3 / 1 4}$ & $\begin{array}{c}\text { Average } \\
\mathbf{0 7 / 8} \text { to } \\
\mathbf{0 9 / 1 0}\end{array}$ & $\begin{array}{c}\text { Average } \\
\mathbf{1 0 / 1 1} \text { to } \\
\mathbf{1 3 / 1 4}\end{array}$ & $\begin{array}{c}\text { \%iffer- } \\
\text { ence }\end{array}$ & $\begin{array}{c}\text { \% } \\
\text { maximum } \\
\text { possible } \\
\text { score }\end{array}$ \\
\hline Eastern Cape & 2.1 & 2.7 & 2.5 & 1.8 & 2.3 & 2.4 & 2.9 & $\mathbf{2 . 4 3}$ & $\mathbf{2 . 3 5}$ & -0.08 & $52 \%$ \\
\hline Free State & 3.8 & 2.5 & 3.3 & 2.7 & 3.5 & 3.5 & 2.9 & $\mathbf{3 . 2 0}$ & $\mathbf{3 . 1 5}$ & -0.05 & $70 \%$ \\
\hline Gauteng & 3.3 & 3.6 & 3.6 & 3.3 & 3.1 & 3.8 & 3.3 & $\mathbf{3 . 5 0}$ & $\mathbf{3 . 3 8}$ & -0.13 & $75 \%$ \\
\hline KwaZulu/Natal & 3.8 & 3.4 & 3.5 & 3.5 & 3.0 & 3.0 & 3.0 & $\mathbf{3 . 5 7}$ & $\mathbf{3 . 1 3}$ & -0.44 & $69 \%$ \\
\hline Limpopo & 3.7 & 3.5 & 3.0 & 2.8 & 2.8 & 2.0 & 2.2 & $\mathbf{3 . 4 0}$ & $\mathbf{2 . 4 5}$ & -0.95 & $54 \%$ \\
\hline Mpumalanga & 3.1 & 2.6 & 3.1 & 3.3 & 3.7 & 3.5 & 3.9 & $\mathbf{2 . 9 3}$ & $\mathbf{3 . 6 0}$ & 0.67 & $80 \%$ \\
\hline Northern Cape & 3.5 & 2.8 & 3.3 & 3.2 & 3.1 & 3.1 & 3.0 & $\mathbf{3 . 2 0}$ & $\mathbf{3 . 1 0}$ & -0.10 & $69 \%$ \\
\hline North West & 3.2 & 3.7 & 3.3 & 3.0 & 3.5 & 3.2 & 3.6 & $\mathbf{3 . 4 0}$ & $\mathbf{3 . 3 3}$ & -0.08 & $74 \%$ \\
\hline Western Cape & 3.8 & 4.1 & 3.4 & 4.1 & 3.8 & 4.0 & 3.8 & $\mathbf{3 . 7 7}$ & $\mathbf{3 . 9 3}$ & 0.16 & $87 \%$ \\
\hline Average & $\mathbf{3 . 4}$ & $\mathbf{3 . 2}$ & $\mathbf{3 . 2}$ & $\mathbf{3 . 1}$ & $\mathbf{3 . 2}$ & $\mathbf{3 . 2}$ & $\mathbf{3 . 2}$ & $\mathbf{3 . 2 7}$ & $\mathbf{3 . 1 7}$ & $\mathbf{- 0 . 1 0}$ & $\mathbf{7 0 \%}$ \\
\hline
\end{tabular}

Source: Own calculations based on data from the National Treasury and Auditor-General 
(75\% of the possible 4.5 score) to a disappointing average PFMP index score of 2.5 between $2010 / 11$ and 2012/13 (54\% of a possible 4.5 score).

The three top achieving PEDs which had performance above the national average in the 6 years under scrutiny were Gauteng, Mpumalanga and the Western Cape. The average PFMP index for Gauteng had declined slightly (from 3.5 between 2007/08 and 2009/10 to 3.4 between 2010/11 to 2013/14), while Mpumalanga and Western Cape PEDs showed steady improvement. Mpumalanga's improvement is particularly noteworthy: increasing its average PFMP index score of 2.9 between 2007/08 and 2009/10 (64\% of the maximum score of 4.5 ) to an average score of 3.6 between 2010/11 to 2013/14 (80\% of the maximum score). The Western Cape Department of Education was the strongest performer, achieving an average score of 3.9 between 2010/11 and 2013/14, 87\% of the maximum possible score of 4.5 .

Based on whether a PED is currently performing above, below or at the national average PFMP index score and whether its average PFMP index has been stable, declining or improving across the two three-year periods under scrutiny, three groups of departments can be discerned:

1. The "Intensive Care Unit": The Eastern Cape and Limpopo Department of Education have not only under-performed the national average, but have actually retrogressed.

2. Stagnating and under observation: PEDs such as KwaZulu-Natal, the North West, the Northern Cape and the Free State are performing at approximately the national average. While the Free State Department of Education has been stagnant over both periods, the others have deteriorated. Leadership instability, 
skills shortages, poor accountability and other root causes need to be addressed as a matter of urgency to pre-empt further decline. Even though Gauteng's score was above the province-wide average, the reduction in its average score between $2009 / 10$ and 2013/14 is cause for deep concern.

3. Steady progress: Mpumalanga and the Western Cape are performing relatively well and should be encouraged to achieve clean audits (i.e. no findings with regard to financial statements, performance information and compliance with all other regulatory requirements).

An analysis of the trends in each of the variables underpinning the PFMP index yielded further insights. Except in the Free State, personnel budget planning and control across PEDs had improved in the wake of the personnel pressures due to poor implementation of OSD. The Eastern Cape and Mpumalanga PEDs have converted their personnel budget overspending of $-5.3 \%$ in $2009 / 08$ and $6 \%$ in 2008/09 to modest surpluses of $0.2 \%$ and $0.7 \%$ respectively in 2013/14. By contrast, the Free State PED overspent its personnel budget by -6.7 percent in $2008 / 09$ and continued to overspend by $-5.1 \%$ in 2013/14.

Similarly, the planning and control of goods and services budgets improved significantly across most PEDs. In the Eastern Cape, the overspending of its goods and services budget of $21.6 \%$ in $2007 / 08$ was converted to a negligible surplus of -1.7 by 2013/14, while in the Gauteng PED, an overspend of $31.6 \%$ in 2007/08 was reduced to $-6.8 \%$ in $2013 / 14$. The major exception was the Limpopo PED where an underspending of the goods and services budget of $10.5 \%$ in $2007 / 08$ declined further to an underspending of $22.5 \%$ in 2013/14 with associated negative impact on the delivery of textbooks, stationery and so forth as the result of personnel over-expenditure in 
preceding years, "crowding out" goods and services spending and ineffective supply chain management.

Underspending of capital budgets has declined markedly between 1997/98 to 2013/14. In several instances however it remains unacceptably high given the substantial backlog in school infrastructure in the poorer provinces. Underspending of capital budgets by $36.0 \%, 37.2 \%, 52.6 \%$ and $38.6 \%$ in the Mpumalanga, Gauteng, Free State and Eastern Cape PEDs respectively in $2010 / 11$ declined to $8.9 \%, 6.8 \%, 13.3 \%$ and $10.9 \%$ of the total appropriated capital budget in 2013/14 respectively. This was due to better infrastructure delivery systems, filling critical vacant posts and technical support for the National Treasury’s Infrastructure Delivery Improvement Project.

Audit opinions by the Auditor-General have improved over the period under review for the Eastern Cape, Gauteng, Mpumalanga, North West and the Western Cape PEDs, which suggest more credible PFM systems. However, in the Free State, KwaZulu-Natal and Limpopo PED audit opinions have deteriorated. In the Free State, Limpopo, North West, Northern Cape PEDs, the number of audit findings in respect of performance information increased during the period under study. Free State, Limpopo and Mpumalanga PEDs experienced difficulty in complying with the new accounting requirements for asset management, resulting in qualifications in their audit opinions. Gauteng, Mpumalanga and the Western Cape PEDs had no audit findings relating to performance information in 2013/14.

Several PEDs have improved compliance with supply chain management regulations and substantially reduced levels of irregular expenditure, such as Mpumalanga, the North West and the Western Cape. In the Eastern Cape PED there has been a decrease 
in irregular expenditure from R3 938 million in 2010/11 to R149 million in 2013/14 due to more effective supply chain management. However, this level of irregular expenditure remains unsatisfactorily high. The Auditor-General reported an alarming increase in irregular expenditure in four PEDs. In the Free State, Gauteng and KwaZulu-Natal PEDs irregular expenditure increased from R93 million, R109 million and R974 million respectively in 2009/10 to R269 million, R233 million and R2 680 million respectively in 2013/14. Irregular expenditure in Limpopo PED also increased substantially from R696 million 2010/11 to R 2209 million in 2013/14. Weaknesses in the supply chain management control environments not only undermine service delivery but also expose these PEDs to heightened risk of fraud and corruption.

Except in Mpumalanga and the Western Cape PEDs which had no leadership and governance findings by the Auditor-General, and to a lesser extent in the Gauteng PED, weaknesses in PFM leadership by AOs and/or CFOs was pervasive and audit committees largely ineffective. The poorest performing PEDs were characterised by a high degree of leadership instability.

Vacancies in both AO and CFO positions in the Eastern Cape PED lead to chronic dysfunction in PFM. The Auditor-General reported "a lack of direction and accountability", "a total breakdown in internal controls and supply chain management" and "findings that are indicative of fraud and corruption" (Auditor-General, 2010:15). Since the national government intervention in 2011 in terms of section 100 of the Constitution, and the appointment of permanent incumbents in $\mathrm{AO}$ and $\mathrm{CFO}$ positions, there has been a marginal improvement in the Eastern Cape PED. Astoundingly high vacancy rate of $69 \%$ in the finance section of the Limpopo PED, severe skills deficits especially in supply chain and asset management and evidence of fraud and corruption 
also triggered national government intervention in this PED in 2011. Despite the support of the National Treasury intervention team, the administrator appointed to take over the Department has failed to turn the Limpopo PED around despite the appointment of a competent $\mathrm{CFO}$ and the filling of critical finance positions (South Africa. Auditor-General, 2013).

In respect of the Western Cape PED, the Auditor-General had made findings in 2007/08 regarding lack of leadership by the Executive Authority (the provincial MEC), the AO and/or the CFO, as well as in respect of financial governance shortcomings and inadequate financial and performance controls. By 2013/14, the Western Cape, the best performing PED with the most stable political-administrative interface, had remedied all these shortcomings, emerging with no findings in respect of leadership, governance or financial and performance controls. The same applied to Mpumalanga PED which had, by $2013 / 14$, responded to and rectified the findings relating to governance and financial and performance control weaknesses noted by the Auditor-General. By contrast, the worst performing PEDs in the "Intensive Care Unit" (Limpopo and the Eastern Cape) have obtained recurring findings relating to poor leadership, governance and financial and performance controls throughout the period under review and have been unable to correct them, partly due to newly appointed political principals wanting to replace existing AOs and CFOs with new appointees of their choice and the long periods taken to fill these vacancies (as discussed above). PEDs in the "Stagnating and under observation" group such as KwaZulu-Natal, the Northern Cape and the Free State have made some progress since 2007/8 in addressing governance weaknesses (e.g. in relation to the effectiveness of audit committees), but have still not resolved all the issues relating to inadequacy of leadership and financial controls. The one notable exception in 
this group is the North West PED which has strengthened its leadership, governance and financial control environments significantly through the appointment of a permanent $\mathrm{AO}$ and CFO in 2009/10. With a financially unqualified audit opinion in 2013/14 and an average PFMP Index score of 3.33 between 2010/11 and 2013/4 (74\% of the maximum possible score), the North West PED may well graduate to the "steady progress" group, if it can maintain this tentative improvement. This analysis suggests that instability in the political administrative interface undermines the quality of financial leadership, governance and the control environment in PEDs, as well as PFM reform outcomes.

\section{IMPLICATIONS FOR THEORY AND PRACTICE}

At inception, the South African PFM reform programme - like those of most other countries - did not explicitly articulate a "theory of change" but seems to have been predicated on a set of implicit assumptions about how the set of proposed reform measures (such as the new PFMA legislation and regulations, new governance structures such as audit committees, new roles and responsibilities for AOs and CFOs, PFM training, technical support and implementation of new PFM systems) would achieve the desired reform objectives. In retrospect after more than 15 years of PFM implementation experience, the findings of this study strongly suggest that insufficient attention has been afforded to ensuring leadership continuity and commitment to reform among AOs and CFOs, to making sure that newly created institutional forms (such as audit committees and other fiscal structures) actually translate into improved governance function rather than merely institutional form and to strengthening fiscal accountability systems. A major lesson learnt from the South African PFM experience 
is the need for developing countries contemplating similar PFM reform to factor in risks related to these factors in the design and implementation of proposed PFM reform trajectories from the start. More qualitative research is however required to understand fully how variations in the local political economy landscape and the interplay of formal and informal institutions shaping shape incentives, behaviours and ultimately implementation outcomes across the nine South African provincial governments. A better understood and explicitly articulated "theory of change" would not only be a major contribution to building theory around PFM reform in developing countries, but also increase the probability of implementation reform success in practice.

The findings of this study also emphasize that stabilising administrative leadership through the appointment of competent AOs and CFOs in PEDs is absolutely critical in driving successful PFM reform forward. This points to a need to reinforce PFM reforms with complementary civil service and administrative reforms, not only in South Africa provincial governments but also other developing countries where governance and accountability institutions are weak. PFM reforms are often seen as more technical and hence more tractable than broader civil service reform, but the South African experience underscores that the anticipated PFM reform outcomes are unlikely to materialize without the latter, another valuable insight for other developing country reform programmes.

The National Development Plan 2030, aiming to stabilise the political-administrative interface in South Africa, has suggested a hybrid approach for top management recruitment which authorizes political input from Ministers into the process but ensures that administrative norms and standards (e.g. competence and experience) are also adhered to. The National Development Plan also envisaged a stronger role for the 
independent Public Service Commission to monitor the top management process. AOs would be given granted authority to make purely administrative appointments for lower level positions (South Africa. National Planning Commission, 2012). The importance of simultaneously strengthening the lines of accountability and consequences for infringing the PFMA while building PFM capacity cannot be over-rated. These findings resonate strongly with Naidoo (2015) who has highlighted institutional instability as a critical factor undermining attempts to build managerial capability in the South African public sector, lack of commitment to key elements of reform such as the delegation of authority to senior public sector managers and the capture and politicisation of administrative structures by party politics.

Beyond the NDP recommendations of for stabilizing the political and administrative interface to enhance leadership continuity, greater emphasis on succession planning and talent management is also essential. Training of CFOs and AOs in South Africa tends to be primarily technically and transactionally oriented, rather than strategic. National and provincial treasuries could be instrumental in ensuring that the curricula of higher education institutions and professional bodies empower CFOs and AOs to lead change. Successful human resource interventions in countries such as Singapore, New Zealand and Thailand highlight the importance of on-the-job developmental experiences in complementing management training, and the need for leadership development strategies to be informed by reform trajectories, departmental medium term goals and individual career paths (Berman, 2015). This would, however, require much close collaboration between the National Treasury and the Department of Public Service and Administration within the national sphere, and the provincial treasuries and Premier's 
Offices in the provincial sphere, than has been evident in PFMA reform implementation hitherto.

The imperative to go beyond technical dimensions of PFM reform to address political economy factors inhibiting reform implementation (such as patronage and weak accountability) has also been advocated in Asia (Turner, 2013) and other developing countries embarking on reform (Andrews, 2011; Brinkerhof and Brinkerhof, 2015). This would certainly also be the case in South African provincial governments. More vigorous oversight by the provincial legislatures of the group of PEDs which are "stagnating and under observation" could materially strengthen accountability channels, complementing monitoring and capacity building efforts by the National Treasury and provincial treasuries. Ultimately, increased electoral competition within the provincial sphere is a crucial political factor in shaping an environment where greater incentives to improve performance create an administrative ethos more conducive to attracting and developing fiscal leadership and embedding a culture of fiscal governance.

\section{CONCLUSIONS}

The PFMP index does not only provide a practical tool for measuring and benchmarking progress with reform, but also provides a platform for future qualitative research into causal factors for the institutional decoupling which seems to have occurred in the Limpopo and Eastern Cape PEDs compared to the factors conducive to meaningful reform in the Mpumalanga and Western Cape PEDs, a critical building block in constructing a "theory of change" in the South African provincial context. 
While the PEDs in the "steady progress" group do not appear to need support from national government, PEDs in the "Intensive Care Unit" require comprehensive and intensive support interventions to re-invigorate PFM reform. More limited but better targeted support programmes should be tailored for the specific weaknesses of PEDs in the "Stagnating and under observation group". These should focus not only on the enhancing technical PFM skills such as supply chain management, asset management and internal audit, but also national government assistance in the recruitment of skilled personnel, especially in rural provinces and regular PFM training programmes given the high levels of turnover among PFM practitioners at the provincial sphere. The recommendations in the National Development Plan to stabilise the politicaladministrative interface should be implemented as a matter of urgency. The PFMP index analysis suggests that an intense focus on leadership, governance and change management to complement existing technical PFM reform support is key to catalysing improved PFM outcomes within the group of PEDs in which PFM reform appears to have run out of steam. The lessons learnt in this process would have broader relevance not only for other departments in the nine provincial governments of South Africa, but also for other developing countries which have embarked on similar PFM reforms and are now grappling with the similar challenge of how to sustain its momentum.

\section{REFERENCES}

Ajam T.2016. Public Financial Management Reforms for Value-for-Money in Selected South African Provincial Governments, Unpublished PhD thesis, University of Pretoria, Pretoria 
Allen R. 2009. The Challenge of Reforming Budgetary Institutions in Developing Countries. Washington, DC: International Monetary Fund

Andrews M. 2008. The good governance agenda: beyond indicators without theory. Oxford Development Studies, 36(4): 379-407.

Andrews M. 2013. The Limits of Institutional Reform in Development. New York: Cambridge University Press.

Andrews, M. 2015. Doing complex reform through PDIA: judicial sector change in Mozambique, Public Administration and Development 35: 288-300, DOI: 10.1002/pad.1740

Berman, EM. 2015, HRM in development: lessons and frontiers, Public Administration and Development 35: 113-127

Black P, Calitz E, Steenekamp, TJ. 2003. Public Economics for South African Students. Oxford University Press: Cape Town:

Boulding P, Mackie A, Ronsholt F, Sharples S. 2012. New development: PEFA-what difference has it made? Public Money and Management 32(1):41-44.

Boyne GA, Farrell C, Law J; Powell M, Walker, R.M. 2003. Evaluating Public Management Reforms. Open University Press: Buckingham.

Brinkerhof, DW, Brinkerhof, JM. 2015. Public sector management reform in developing countries: perspectives beyond NPM orthodoxy, Public Administration and Development 35:222-237, DOI: 10.1002/pad.1739

Bunse S, Fritz V. 2012.Making public sector reforms work: political and economic contexts, incentives, and strategies. World Bank Policy Research Working Paper, no. 6174. Available at: http://papers.ssrn.com/sol3/papers.cfm? abstract_id=2133115 [Accessed on 3 November 2014].

Caiden N, Wildavsky A. 1970. Planning and Budgeting in Poor Countries John Wiley and Sons: New York.

Cummings C. 2015. Fostering innovation and entrepreneurialism in public sector reform, Public Administration and Development 35: 315-328, DOI: 10.1002/pad.1735

Diamond J. 2003. Performance Budgeting: Managing the Reform Process. Washington, DC: International Monetary Fund.

Douglas JW. 2000. Budget reform theory: a guideline for successful budget reform. International Journal of Public Administration 23(11):1967-1996. 
Folscher A, Cole N. 2006. South Africa: transition offers opportunities for whole system reform. Available at: http://www.oecd.org/dataoecd/24/61/43470149.pdf (Accessed on 13.12.2013).

Gao, J. 2015. Performance measurement and management in the public sector: some lessons from research evidence, Public Administration and Development 35: 8696. DOI: $10.1002 /$ pad. 1704

Goldfinch S, Derouen K, Pospieszna P. 2013. Flying blind? Evidence for good governance public management reform agendas, implementation and outcomes in low income countries. Public Administration and Development 33:50-61.

Gray A, Jenkins W. 2004. Government and administration: too much checking, too little doing. Parliamentary Affairs 57(2):269-287.

Guess GM, Ma, J. 2015. The risks of Chinese subnational debt for public financial management. Public Administration and Development 35:128-139

Guthrie J, Humphrey C, Jones LR, Olson, O. 2005. International Public Financial Management Reform: Progress, Contradictions and Challenges. New Age Publishers: Greenwich, Connecticut:

Guthrie J, Olson O, Humphries C. 1999. Debating developments in new public financial management: the limits of global theorising and some new ways forward. Financial Accountability and Management 15(3):209-228.

Hepworth N. 2015. Debate: Implementing advanced public financial management reform in developing countries. Public Money and Management 35:4:251-253.

Jones LR, Kettl DF. 2003. Assessing public management reform in an institutional context. International Public Management Review 4(1): 1-18.

Levy N, Tapscott C. 2001. Intergovernmental Relations in South Africa: The Challenges of Co-operative Government. Idasa: Cape Town:

Marti C, Kasperskaya Y. 2015. Public financial management systems and countries' governance: a cross-sectional study. Public Administration and Development (2015) DOI: 10.1002/pad (Accessed 12.7.2015)

Naidoo, V. 2015. Changing conceptions of public 'management' and public sector reform in South Africa, International Public Management Review, 16(1):23-42

Newbery S, Pallot J. 2005. New Zealand Public Management and Accounting Reforms: The Hidden Agenda. In: Guthrie J, Humphrey C, Jones LR, Olson, O. eds. International Public Financial Management Reforms. Information Age Publishing: Greenwich, Connecticut, 169-194. 
Overseas Development Institute. 2007. Tales of the unexpected: public financial reform in difficult environments. Centre for Aid and Public Expenditure: London.

PEFA 2006. Public Financial Management Performance Measurement Framework, World Bank: Washington DC.

Pollitt C. 1995. Justification by works of by faith? Evaluating the New Public Management. Evaluation, 1(2):133-154.

Pollitt C, Boukaert G. 2011. Public Management Reform A Comparative Analysis: New Public Management, Governance and the Neo-Weberian State, Oxford University Press: Oxford:

Puppim de Oliviera, JA, Jing, Y, Collins, P. 2015. Public Administration for development: trends and the way forward, Public Administration and Development 35: 65-7, DOI: 10.1002/pad.1716

Quist RE, Certan C, Dendura J. 2008. Republic of South Africa Public Expenditure and Financial Accountability: Public Financial Management Performance Assessment Report. Available at: ECORYShttp://www.treasury.gov.za/ publications/other/Final\%20PEFA\%20Report\%20-\%2029\%20Sept\%202008.pdf (Accessed on 12.8.2013).

Repucci S. 2014. Designing effective civil service reform: lessons from past experience. Public Administration and Development 34: 207-218.

Rinnert, D. 2015. The politics of civil service and administrative reforms in development - explaining within-country variation of reform outcomes in Georgia after the Rose Revolution, Public Administration and Development 35: 19-33, DOI: 10.1002/pad.1709

Schick A. 1998. Why most developing countries should not try New Zealand reforms. World Bank Research Observer, 13(1):123-31.

Shamsul Haque, M. 2013. Public administration in a globalized Asia: intellectual identities, challenges, and prospects, Public Administration and Development 35: 262-274. DOI: 10.1002/pad.1658

Smoke, P. 2015. Rethinking decentralization: assessing challenges to a popular public sector reform, Public Administration and Development 35: 97-112, DOI: 10.1002/pad.1703

South Africa (Republic) 1996. Constitution of the Republic of South Africa of 1996. Pretoria, Government Printers. 
South Africa (Republic) 1999. Public Finance Management Act, 1999 (Act 1 of 1999). Pretoria, Government Printer.

South Africa. Auditor General. 2010. Eastern Cape General Report on the Audit Outcomes of Provincial Government for the Financial Year 2009-10. Available at: http://www.agsa.co.za/Documents/Auditreports/

PFMAgeneralreportsprovincial.aspx (Accessed on 28.2.2011):

South Africa. Auditor General. 2013a. Consolidated General Report on the National and Provincial Audit Outcomes 2012-13. Available at: http://www.agsa.co.za/Documents/Auditreports/ (Accessed on 21.2.2015).

South Africa. Auditor General, 2013b. Limpopo General Report on the Audit Outcomes of Provincial Government for the Financial Year 2012-13. Available at: http://www.agsa.co.za/Documents/Auditreports/PFMAgeneralreportsprovincial. aspx: (Accessed on 28.2.2015).

South Africa. National Planning Commission. 2012. Our Future - Make It Work. Available at: http://www.npconline.co.za/MediaLib/Downloads/Downloads/ NDP\%202030\%20-\%200ur\%20future\%20-\%20make\%20it\%20work.pdf (Accessed on 18.8.2014)

South Africa. National Treasury. 2015a. Budget Review 2015. Pretoria, Government Printers.

Statistics South Africa 2014. Poverty Trends in South Africa. Available at: http://www.statssa.gov.za/publications/Report-03-10-06/Report-03-1006March2014.pdf (Accessed on 14.7.2015).

Turner, M. 2013. Why is it so difficult to reform some Asian bureaucracies? Building theory from Cambodian evidence, Public Administration and Development 35: 275-285. DOI: 10.1002/pad.1655

Wildeman R, Jogo W. 2012. Implementing the Public Finance Management Act in South Africa: How Far Are We? Idasa Economic Governance Programme: Pretoria:

World Bank. 2008. Public Sector Reform: What Works and Why. World Bank: Washington D.C. 


\section{ANNEXURE 1: PFMP INDEX VARIABLES FOR PROVINCIAL EDUCATION DEPARTMENTS}

\begin{tabular}{|c|c|c|c|c|c|c|c|c|c|c|c|c|c|c|c|}
\hline EASTERN CAPE & WEIGHT & \multicolumn{2}{|c|}{$2007 / 08$} & \multicolumn{2}{|c|}{$2008 / 09$} & \multicolumn{2}{|c|}{$2009 / 10$} & \multicolumn{2}{|c|}{ 2010/11 } & \multicolumn{2}{|c|}{ 2011/12 } & \multicolumn{2}{|c|}{$2012 / 13$} & \multicolumn{2}{|c|}{ 2013/14 } \\
\hline $\begin{array}{l}\text { Compensation of } \\
\text { Employees budget } \\
\text { deviation }\end{array}$ & $10 \%$ & $1.1 \%$ & 5 & $0.0 \%$ & 5 & $-5.3 \%$ & 4 & $-2.9 \%$ & 5 & $-1.8 \%$ & 5 & $1.3 \%$ & 5 & $0.2 \%$ & 5 \\
\hline $\begin{array}{l}\text { Goods and services } \\
\text { budget deviation }\end{array}$ & $10 \%$ & $-21.6 \%$ & 2 & $2.6 \%$ & 5 & $4.3 \%$ & 5 & $21.4 \%$ & 2 & $-1.5 \%$ & 5 & $1.8 \%$ & 5 & $-1.7 \%$ & 5 \\
\hline $\begin{array}{l}\text { Transfer budget } \\
\text { deviation }\end{array}$ & $10 \%$ & $12.2 \%$ & 3 & $-1.5 \%$ & 5 & $4.8 \%$ & 5 & $9.3 \%$ & 4 & $-1.5 \%$ & 5 & $8.5 \%$ & 4 & $-4.0 \%$ & 5 \\
\hline $\begin{array}{l}\text { Capital budget } \\
\text { deviation }\end{array}$ & $10 \%$ & $23.7 \%$ & 2 & $0.2 \%$ & 5 & $7.5 \%$ & 4 & $56.2 \%$ & 0 & $29.5 \%$ & 1 & $-6.7 \%$ & 4 & $10.9 \%$ & 3 \\
\hline $\begin{array}{l}\text { Financial audit } \\
\text { opinion }\end{array}$ & $20 \%$ & A & 1 & A & 1 & $\mathrm{D}$ & 1 & $\mathrm{D}$ & 1 & $\mathrm{D}$ & 1 & Q & 2 & Q & 2 \\
\hline $\begin{array}{l}\text { Audits of } \\
\text { Predetermine } \\
\text { Objectives }\end{array}$ & $10 \%$ & CUR & 1 & $\mathrm{~T}$ & 1 & CURT & 0 & UR & 2 & UR & 2 & $\mathrm{CU}$ & 2 & UR & 2 \\
\hline $\begin{array}{l}\text { Irregular expenditure } \\
\text { ( } \mathrm{R} \text { million) }\end{array}$ & $10 \%$ & 131.0 & 2 & 1551.0 & 0 & 658.0 & 0 & 3938.0 & 0 & 858.6 & 0 & 631.9 & 0 & 149.3 & 2 \\
\hline $\begin{array}{l}\text { Fruitless and wasteful } \\
\text { expenditure ( } \mathrm{R} \\
\text { million) }\end{array}$ & $10 \%$ & 18.1 & 4 & 47.9 & 4 & 0 & 5 & 90.5 & 3 & 54.5 & 3 & 631.3 & 0 & 51.4 & 3 \\
\hline $\begin{array}{l}\text { Leadership, } \\
\text { governance and } \\
\text { financial management } \\
\text { and performance } \\
\text { controls }\end{array}$ & $10 \%$ & LGF & 0 & LGF & 0 & LGF & 0 & LGF & 0 & LGF & 0 & LGF & 0 & LGF & 0 \\
\hline PFMP INDEX & $100 \%$ & & 2.1 & & 2.7 & & 2.5 & & 1.8 & & 2.3 & & 2.4 & & 2.9 \\
\hline
\end{tabular}




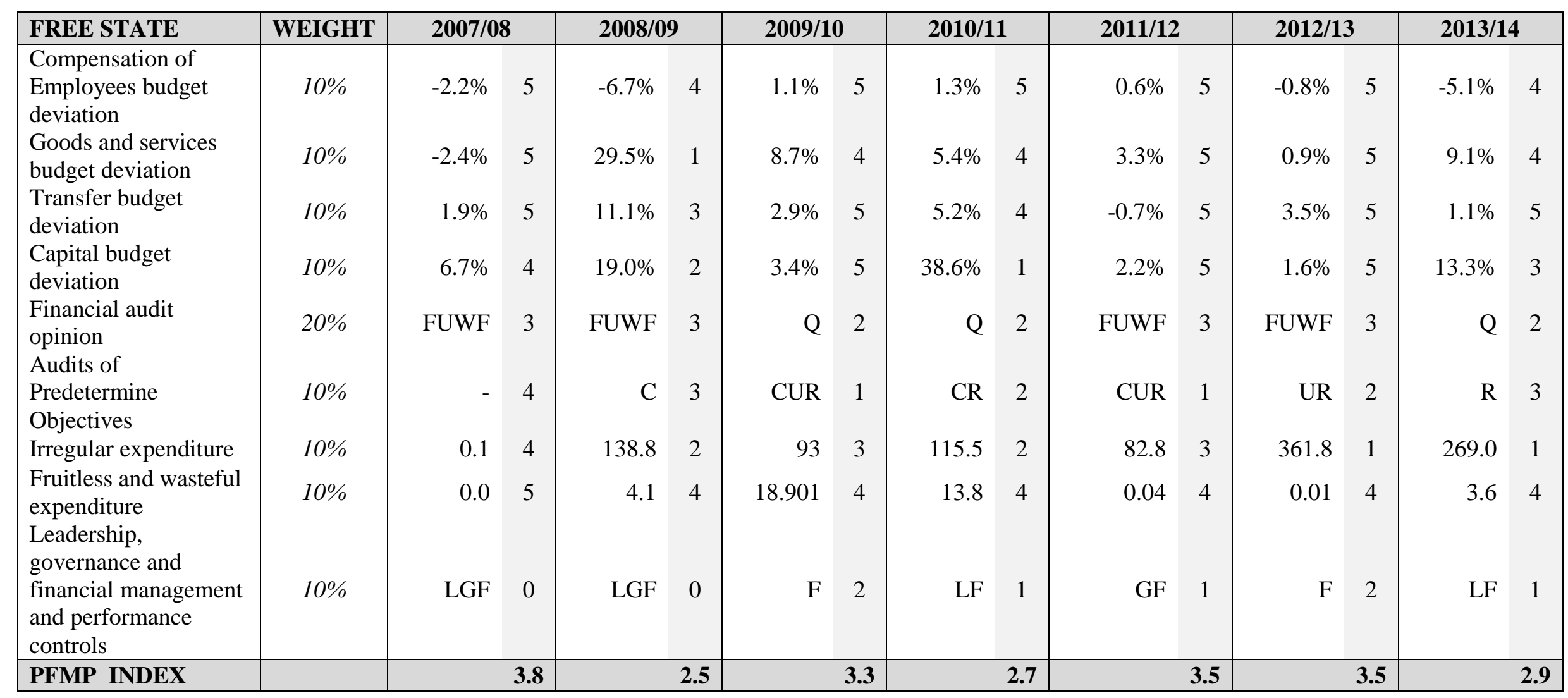




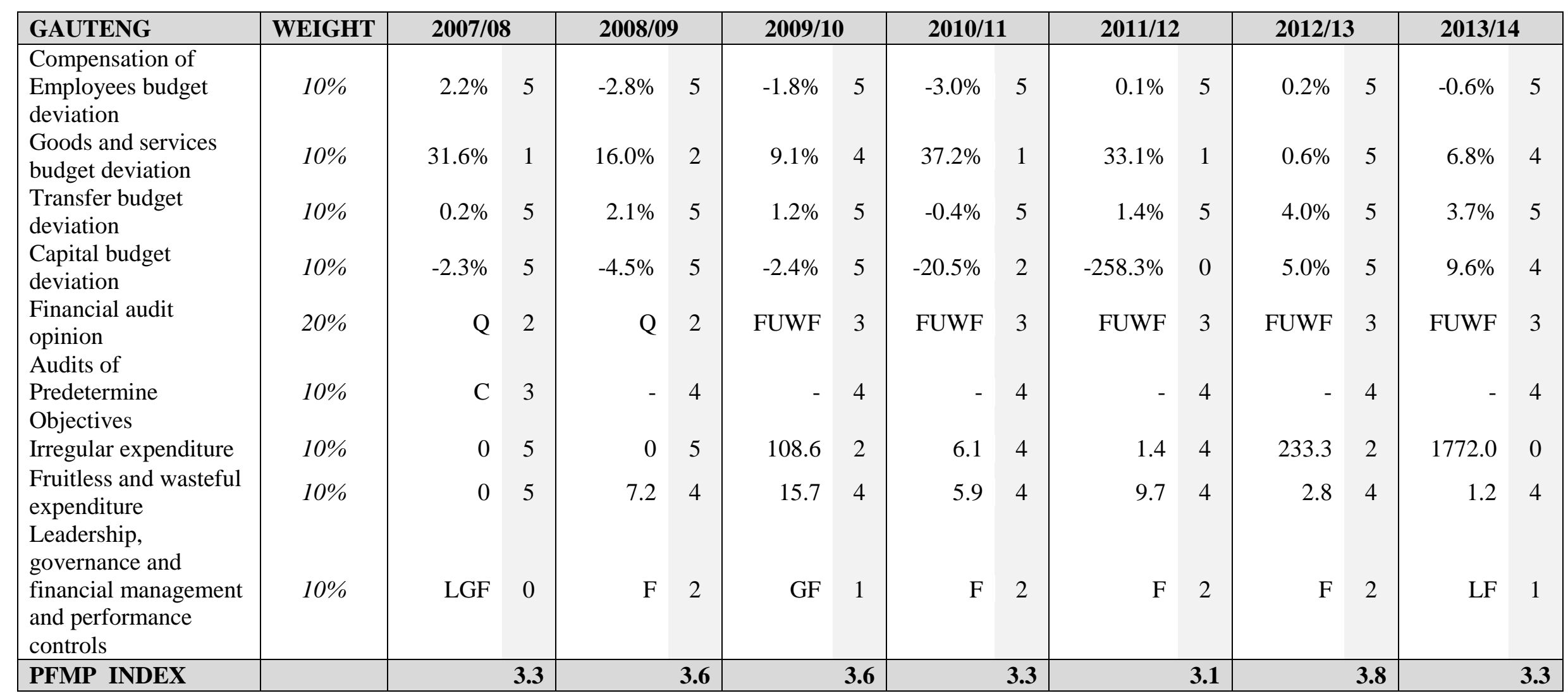




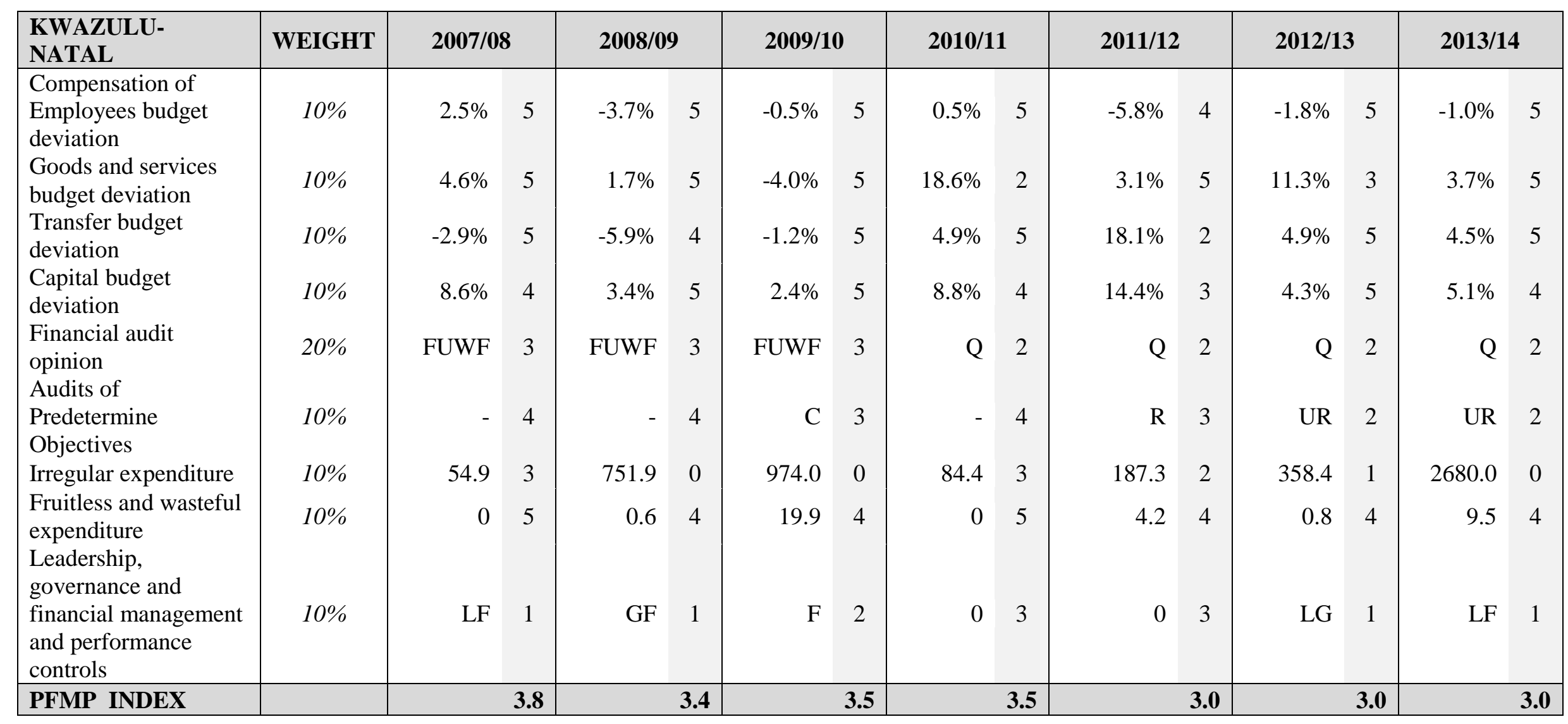




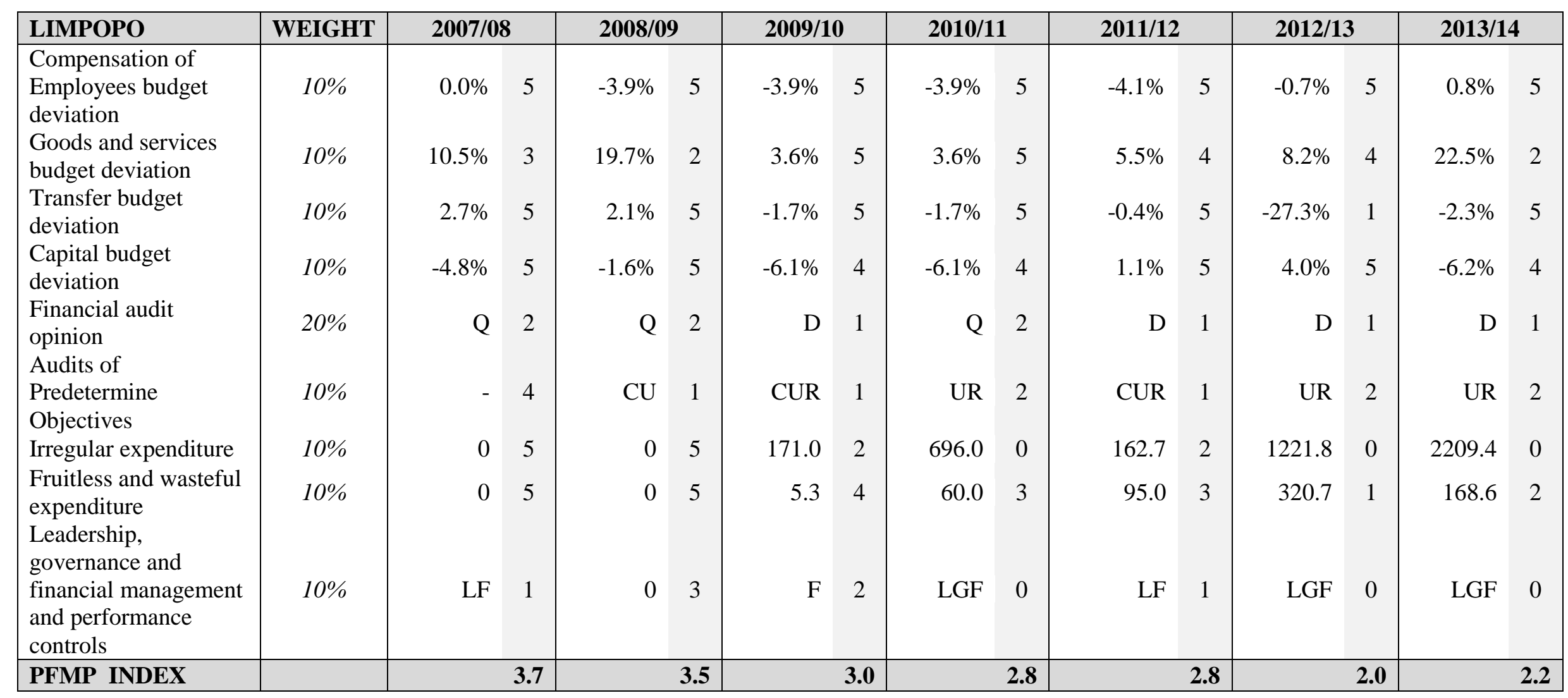




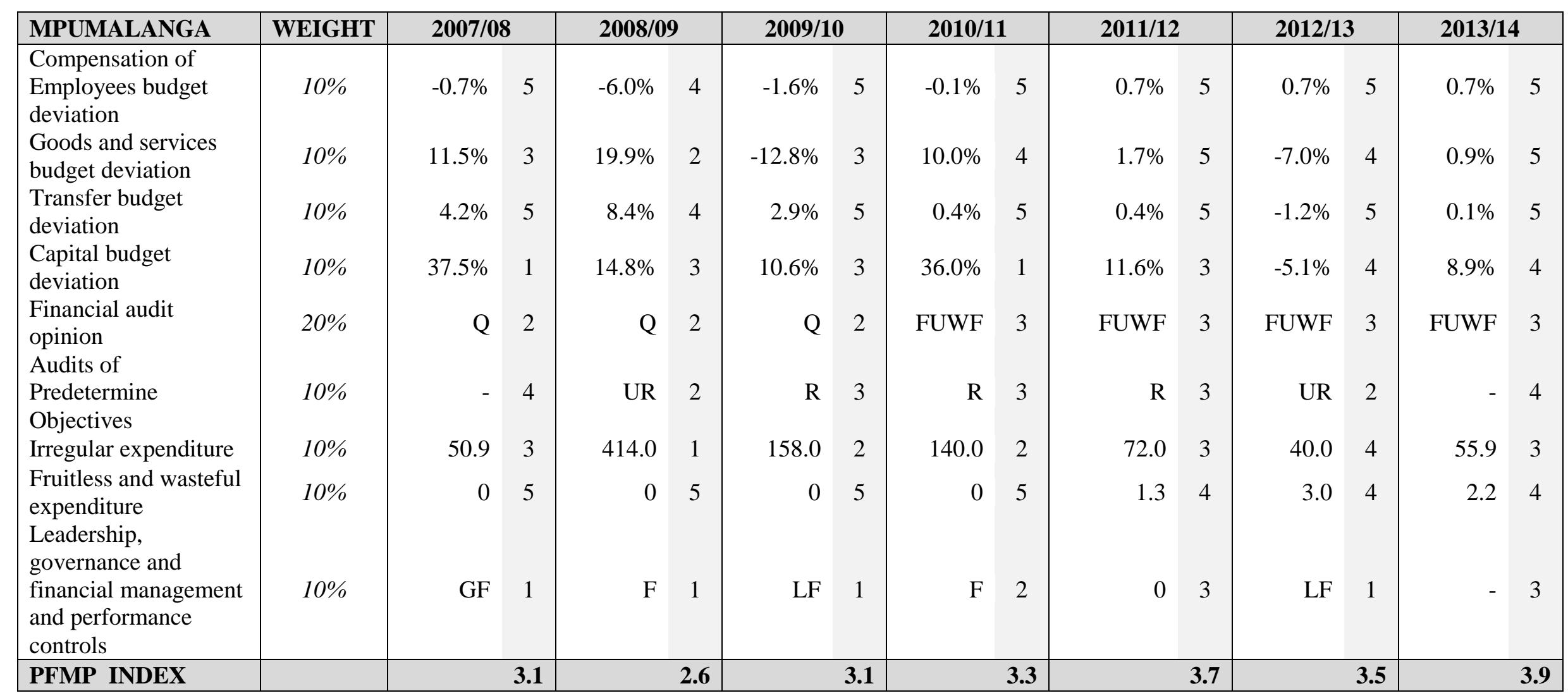




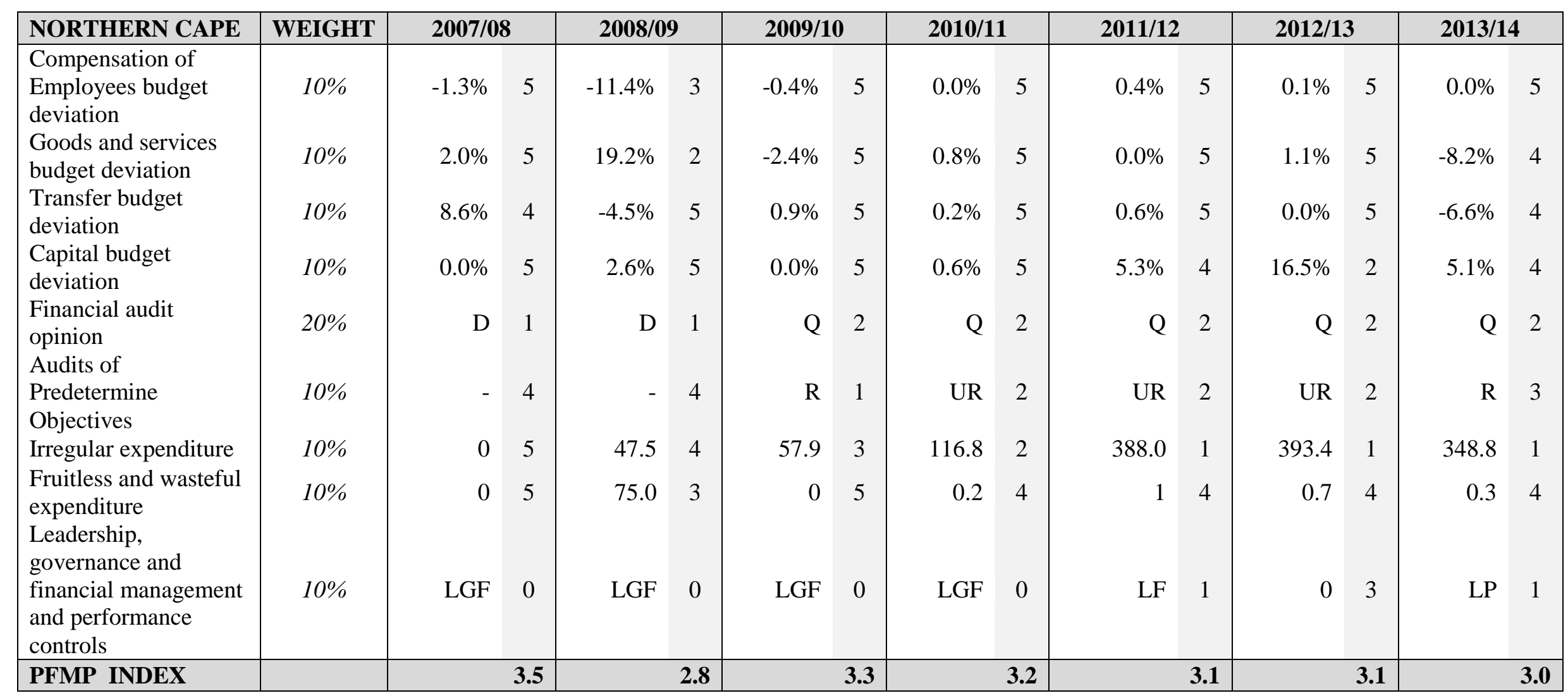




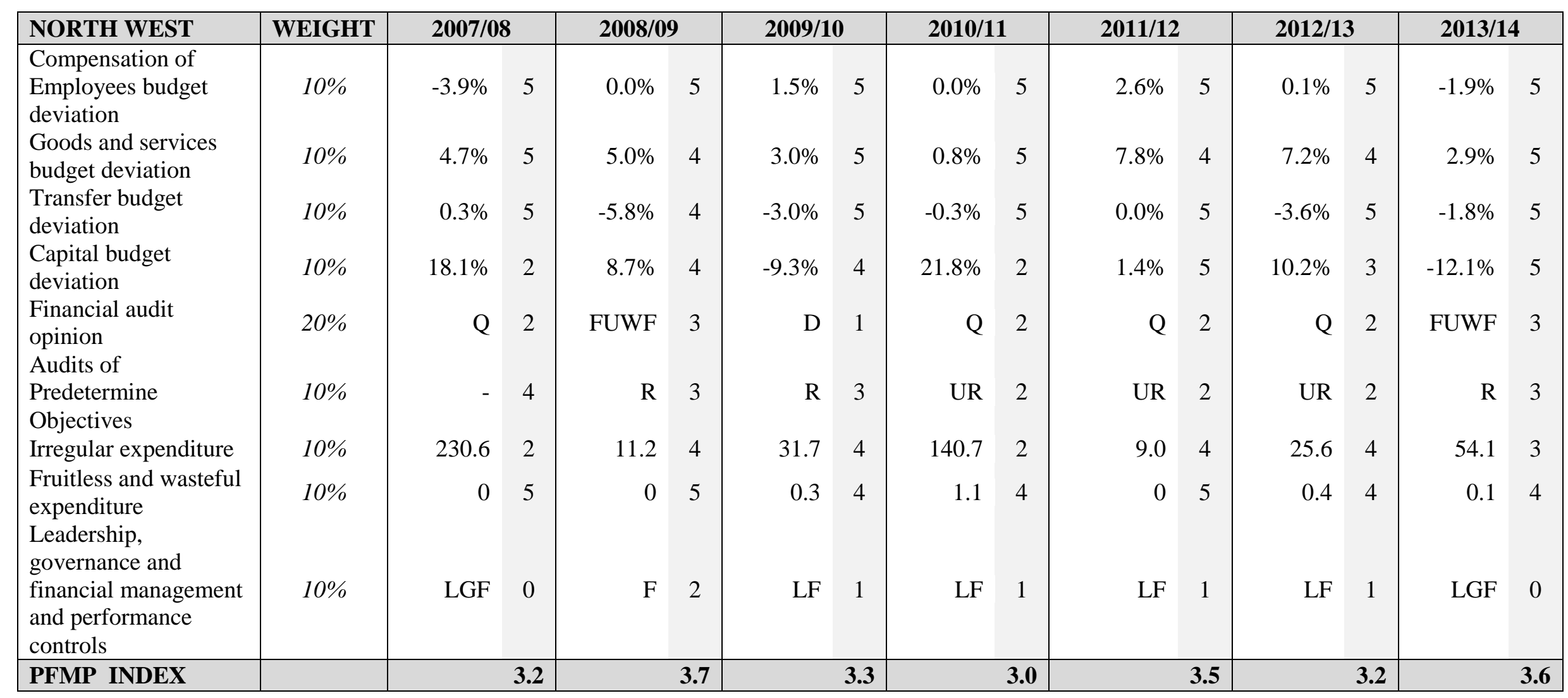




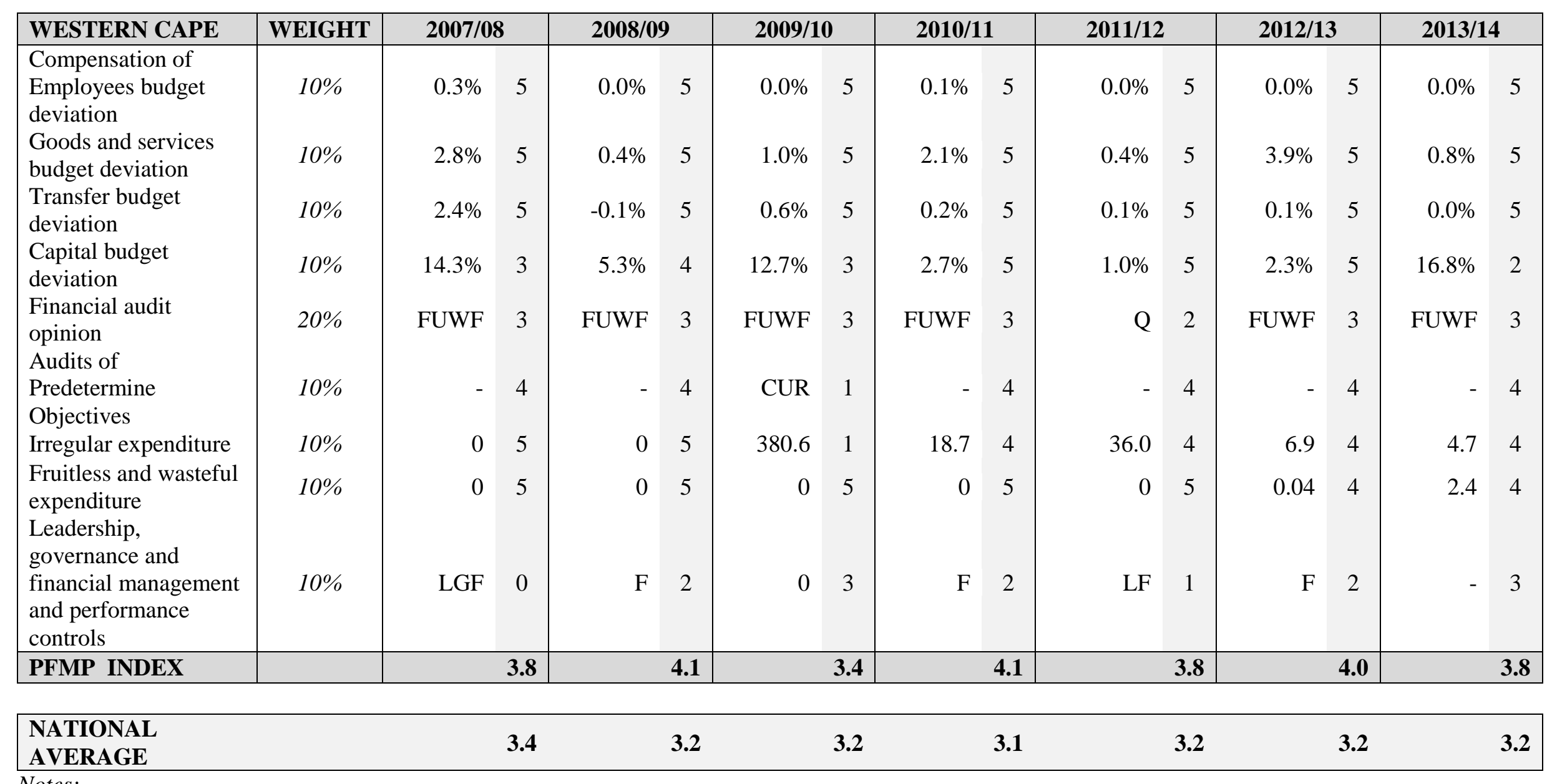

\section{Notes:}

Negative deviations indicate overspending as a percentage of total expenditure, positive deviations indicate underspending as a percentage of total expenditure

Financial audit opinion codes:

$A=$ adverse, $D=$ disclaimer, $Q=$ Qualified, $F U W F=$ Unqualified with findings, $F U=$ financially unqualified 
Audits of Predetermined Objectives findings codes :

$T=$ not submitted by legislated date, $C=$ compliance finding, $U=$ performance information not useful, $R=$ performance information not reliable Leadership and governance findings:

$L=$ leadership not fulfilling roles, $G=$ governance weaknesses e.g. in internal audit or audit committee, $F=$ financial controls weaknesses

Source: Own calculation using financial and non-financial data from departmental annual reports in the National Treasury database and AuditorGeneral reports 